\title{
Genetic Analysis of Yield and Related Characters of Lablab Bean
}

\author{
Md. Borhan Uddin Rony, AKM Aminul Islam ${ }^{\circledR}$, Md. Golam Rasul and Mohammad Zakaria \\ Bangabandhu Sheikh Mujibur Rahman Agricultural University, Gazipur 1706, Bangladesh; @: \\ aminulgpb@bsmarau.edu.bd
}

Received 1 Jan 2019, Revised 17 Feb 2019, Accepted 15 March 2019, Published 28 April 2019

Scientific Editors: Puspa Raj Paudel, Shambhu Khatiwada, Jiban Shrestha Copyright $\odot 2019$ NARC. Permits unrestricted use, distribution and reproduction in any medium provided the original work is properly cited. The authors declare that there is no conflict of interest.

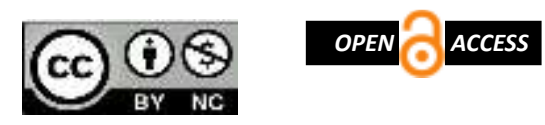

Licensed under the Creative Commons AttributionNonCommercial 4.0 International (CC BY-NC 4.0)

\begin{abstract}
An experiment was conducted with a view to determine the nature and extent of gene action of yield and yield related characters of lablab bean. Five parents and their $10 \mathrm{~F}_{1} \mathrm{~s}$ synthesized from $5 \mathrm{x} 5$ half diallel cross were evaluated in a Randomized Complete Block Design with three replications. The analysis of variance showed that the difference among the genotypes (parents and $F_{1} s$ ) were highly significant for all the characters which revealed the presence of wide variability among the genotypes under this study. Hayman's ANOVA (modified by Jones) suggested that the presence of additive and dominance gene actions for all the characters. The ' $\mathrm{Vr}$ Wr' graph indicated partial dominance for the characters viz. days to first inflorescence appearance, days to first flowering, days to pod maturity, days to seed maturity, number of nodes per inflorescence, edible pod length, edible pod breadth, edible pod weight and pod yield per plant. Over dominance was observed for number of inflorescences per plant, number of pods per inflorescence and hundred seed weight. Complete dominance was observed only for number of pods per plant in lablab bean. As the development of hybrid variety is not possible in lablab bean, diallel selective mating system may be adopted for improvement of yield traits by using knowledge of gene actions. The hybrids with predominant additive gene action for yield related traits may be advanced to obtain transgressive segregants and pure lines for higher pod yield per plant.
\end{abstract}

Keywords: Country bean, diallel, dominance, gene action, earliness, pod yield

\section{INTRODUCTION}

Lablab bean (Lablab purpureus L.) is a popular winter vegetable crop in Bangladesh. It is a species of bean in the family of Fabaceae. This is popularly known as country bean or Deshi seem in Bangladesh. It is a self-pollinated crop that has a set of diploid chromosome $(2 n=2 x=20,22,24)$ (Philip, 1982). Lablab bean is cultivated to wide areas under diverse climatic conditions. It is grown well where daily temperature range from $17^{\circ}-30^{\circ} \mathrm{C}$ and can widely be cultivated from sand to clay soil, in a pH range of 4.5-7.5 (Cook et al 2005). The commercial cultivation of lablab bean relates also in poor sandy to medium loam soil. It has been reported that lablab bean does not grow well in saline or poorly-drained soils, but it grows better than most legumes under acidic condition (Valenzuela and Smith, 2002). Being a drought tolerant crop, it grows well in dry lands with limited rainfall. It can continue to grow in drought or shady conditions, and well grow in areas with an average annual rainfall is $25-120 \mathrm{~cm}$ (Cook et al 2005). It is well suited to arid and warm climates where rainfall is around $600 \mathrm{~mm}$ during the growing season (Cobley and Steele, 1976). Lablab bean is more drought resistant than other similar legumes (Maass et al 2010), and can access soil water 180 $\mathrm{cm}$ deep (Cook et al 2005). It prefers relatively cool seasons (temperature ranging from $14-28^{\circ} \mathrm{C}$ with the sowing done in July-August. The crop starts flowering in short days (11-11.5 hour's day length) and continues indeterminately in spring. It was found that lablab bean flowers throughout the growing season (Kumar et al 2013).

Different cultivars of bean are used for different purpose. It has been estimated that, lablab bean seed contain $19-31 \%$ protein, $2 \%$ fat, $61 \%$ carbohydrate (includes $5 \%$ fibers) as well as adequate levels of vitamins and minerals (Kumar et al 2014). Maass et al (2010) found protein isolate from the bean can 
be used as a food additive for improving cake quality. Edible pods of lablab bean provide substantial amount of protein in addition to vitamin A, vitamin C, riboflavin, potassium, sulphur iron, and sodium (Deka and Sarker 1990, Newaz 1992). The flavonoid overlaid in lablab bean play a role in the prevention of cancer (Kobayashi et al 2002) and as a chemotherapeutic and/or chemo preventive agent for head and neck cancer (Alhasan et al 2001). Polyphenol oxidase like tryrosinase is present in plant tissue of lablab bean has potential for the treatment of hypertension in humans (Naeem et al 2009). Thus mature seed provide a cheaper source of protein that consume at both as cooking and frying. Apart from consuming as vegetable or pulse in Asia, lablab bean is widely grown as a forage or green manure crop in the tropics and subtropics (Purseglove 1977). Being a legume, it can also fix atmospheric nitrogen to the extent of $170 \mathrm{~kg} / \mathrm{ha}$ besides leaving enough crop residues to enrich the soils with organic matter.

According to the latest statistics, the total lablab bean production was 93055, 94356 and 94756 metric ton in the year of 2012-2013, 2011-2012 and 2010-2011, respectively in Bangladesh from 42129, 4230042760 acres of land (BBS, 2014). Thus production is decreased proportionally with decreasing area. The average yield of lablab bean was 5.45 metric ton per hectare during the year 2012-2013 (BBS 2014). Maass et al. (2010) also observed that lablab bean may suffer from low yields when grown as a main cash crop. This poor figure is a matter of lackadaisical for bean production in Bangladesh. However, this low yield status is attributed due to the lack of high yielding varieties and prescribed production practices. Besides this low productivity, crop has others problem in the people in Bangladesh. Most of the farmers of Bangladesh are very poor. They want to get good profit early in the season. The cultivars photosensitivity and longer duration is a great problem in this regard. Again, consumer preferences also vary with pod size, shape, color and aroma. The efforts of improving the crop by utilizing indigenous and exotic germplasm have been useful in breaking the yield barriers (Shivashankar and Kulkarni 1989, Shivashankar et al 1993) resulting in compact plant type, reduced duration and photo-insensitive types.

Hybridization among different genotypes and genetic analysis of different yield and related characters of lablab bean measures the potential of breeding program. Thus it is important to assess breeding potential of parents and select good combiners in lablab bean. Success of any breeding program is relied on choice of parents. This study depicts the nature and magnitude of gene action regarding evolving related characters of parents and their offspring. Gene actions may show heterosis in $\mathrm{F}_{1}$ or linkage in other generation. Thus crop improvement programs are created by this necessary information of fixable genes and exploitation of heterosis. Being a self-pollinated crop, it is estimated theoretically less degree of heterosis. But this study provides higher heterosis in relation to yield trait that helps for increasing the higher production.

Little information has been obtained on the various types of gene action and their relative importance in the inheritance of important traits in lablab bean. Plant breeders are primarily concerned with the improvement of those traits which are directly or indirectly related to the economic values (Wynne and Coffelt 1973). Such traits are generally quantitative in nature and governed by several numbers of genes each having small effect and acting in a cumulative manner called polygenes (Srivastaba and Bajpai 1977). Among the various biometrical tools, diallel analyses furnish fruitful result for identification of genetic parameters regarding combining ability as well as dominance relationship of the parents with their gene effects by studying the $F_{1}$ hybrids. It is also provides information on the nature and magnitude of genetic variance on which success of plant breeding depends. Based on above facts present research was conducted with the objective to estimate the nature and extent of gene action of yield and related characters in lablab bean.

\section{MATERIALS AND METHODS}

Vr-Wr Analysis (Hayman's Approach)

Diallel analysis has been widely used in genetic analysis of quantitative characters in many crop plants. Diallel cross was analyzed with statistical techniques first by Sprague and Tatum (1942). 
Hayman analysis of variance : The Hayman analysis of variance was carried out following Morley Jones modifications for diallel without reciprocals (Jones, 1965) using mean value of diallel fashion.

Where,

$\mathrm{a}=$ additive effects

$\mathrm{b}_{1}=$ mean dominance

$\mathrm{b}_{2}=$ additional dominance effects that can be accounted for by genes having one allele present in only one line the remaining $\mathrm{n}-1$ lines being assumed to carry same alternative allele (= dominance deviation due to arrays)

$\mathrm{b}_{3}=$ residual dominance effects

$\operatorname{dev}^{2}=$ sum of square of deviations from the mean

ur $=$ Yi. + Yii

$\operatorname{tr}=2(Y i .+Y i i)-(p+2) Y i i$

Vr-Wr analysis and graphical presentation: The $\mathrm{Vr}-\mathrm{Wr}$ analysis facilitates study of major genetic features of quantitative characters (Hayman, 1954). The array variance (Vr) and parent offspring covariance (Wr) and regression $\mathrm{Wr}$ on $\mathrm{Vr}$ was calculated to test the adequacy of the simple additive dominance genetic model, to discern the relative proportion of dominant to recessive genes present in the common parents of the arrays and to find average level of dominance.

The parabola $\mathrm{Wr}=\sqrt{\mathrm{V}_{\mathrm{p}} \cdot \mathrm{V}_{\mathrm{r}}}$ in the $\mathrm{Vr}-\mathrm{Wr}$ graph delimits the area in which the coordinate $(\mathrm{Vr}, \mathrm{Wr})$ array data occur and the $\mathrm{Wr}$ intercepts is an indicator of the average degree of dominance, being positive with partial dominance and negative with over dominance. If there is no dominance all the points on the $\mathrm{Vr}$, $\mathrm{Wr}$ graph are estimates of single point $(\mathrm{Wr}, \mathrm{Vr}$ ) with $\mathrm{Wr}=2 \mathrm{Vr}$, there is no regression and the line is tangent to the limiting parabola, with complete dominance, the regression line is of unit slope and passes through the origin.

The variance $(\mathrm{Vr})$ and covariance $(\mathrm{Wr})$ of array whose common parent bears most of the dominant genes will be relatively smaller in magnitude than the array whose common parent carries most of the recessive genes. Parents with dominant allele will have low $\mathrm{Vr}$ and $\mathrm{Wr}$ and will be near the origin while highly recessive parents have large $\mathrm{Vr}$ and $\mathrm{Wr}$ and will be furthest from the origin.

Standard deviation graph was plotted from the standardized values of parental mean ( $\left.\mathrm{Yr}^{\prime}{ }^{\prime}\right)$ and $(\mathrm{Wr}+$ Vr) ${ }_{i}$ values from $n$ arrays, using suitable scale. The intersecting points will locate the relative distribution of array points (parents) in the standardized graphs having four quarter specified by predominance of dominant/recessive alleles with positive/negative effects.

Genetic Components of Variation: The genetic components of variation in $\mathrm{F}_{1}$ diallel population were calculated according to Jinks (1956) as follows:

$\mathrm{D}=\mathrm{V}_{0} \mathrm{~L}_{0}-\mathrm{E}=$ Variation due to additive effect

$\mathrm{F}=2 \mathrm{~V}_{0} \mathrm{~L}_{0}-4 \mathrm{~W}_{0} \mathrm{~L}_{01}-2(\mathrm{p}-2) \mathrm{E} / \mathrm{p}=$ Mean co-variance of additive and dominance effects.

$\mathrm{H}_{1}=\mathrm{V}_{0} \mathrm{~L}_{0}+4 \mathrm{~V}_{1} \mathrm{~L}_{1}-4 \mathrm{~W}_{0} \mathrm{~L}_{01}-(3 \mathrm{p}-2) \mathrm{E} / \mathrm{p}=$ component of variation due to the dominance effect of the genes.

$\mathrm{H}_{2}=4 \mathrm{~V}_{1} \mathrm{~L}_{1}-4 \mathrm{~V}_{0} \mathrm{~L}_{1}-2 \mathrm{E}=\mathrm{H}_{1}\left[1-(\mathrm{u}-\mathrm{v})^{2}\right]=$ proportion of positive genes $\mathrm{U}$ and proportion of negative $\mathrm{V}$ in the parents.

$\mathrm{h}_{2}=4\left(\mathrm{ML}_{1}-\mathrm{ML}_{0}\right)^{2}-4(\mathrm{p}-1) \mathrm{E} / \mathrm{p}^{2}=$ dominance effect (as the algebraic sum over all loci in heterozygous phase in all crosses).

$\mathrm{E}=[($ Error SS + Rep. SS $) / \mathrm{df}$.$] / no. of reps. = the expected environmental component of$ variation.

Where,

$\mathrm{V}_{0} \mathrm{~L}_{0}=$ variance of parents

$\mathrm{V}_{1} \mathrm{~L}_{2}=$ mean variance of the arrays

$\mathrm{W}_{0} \mathrm{~L}_{01}=$ the mean covariance between the parent and the arrays

$\mathrm{V}_{0} \mathrm{~L}_{1}=$ Variance of the mean of arrays

$\left(M L_{1}-M L_{0}\right)^{2}=$ the difference between the mean of the parents and the mean of their $\mathrm{P}_{2}$ progeny. 
The significance of the estimates of various components were tested by calculated their corresponding standard errors.

The standard error is the under root of the products of common multiplier and specific multipliers calculated from the formula as follows:

Common multiplier or variance $\left(\mathrm{S}^{2}\right)$ was calculated with the formula -

$\mathrm{S}^{2}=1 / 2[\operatorname{var}(\mathrm{Wr}-\mathrm{Vr})]$

Specific multipliers of various components are calculated from the formula as follows:

$\mathrm{D}=\left(\mathrm{p}^{5}+\mathrm{p}^{4}\right) / \mathrm{p}^{5}$

$\mathrm{F}=\left(4 \mathrm{p}^{5}+20 \mathrm{p}^{4}-16 \mathrm{p}^{3}+16 \mathrm{p}^{2}\right) / \mathrm{p}^{5}$

$\mathrm{H}_{1}=\left(\mathrm{p}^{5}+41 \mathrm{p}^{4}-12 \mathrm{p}^{3}+4 \mathrm{p}^{2}\right) / \mathrm{p}^{5}$

$\mathrm{H}_{2}=36 \mathrm{p}^{4} / \mathrm{p}^{5}$

$\mathrm{h}_{2}=\left(16 \mathrm{p}^{4}+16 \mathrm{p}^{2}-32 \mathrm{p}+16\right) / \mathrm{p}^{5}$

$\mathrm{E}=\mathrm{p}^{4} / \mathrm{p}^{5}$

Thus, the components of variation with their standard errors are as:

$\mathrm{D} \pm \mathrm{SE}(\mathrm{D})$

$\mathrm{F} \pm \mathrm{SE}(\mathrm{F})$

$\mathrm{H}_{1} \pm \mathrm{SE}\left(\mathrm{H}_{1}\right)$

$\mathrm{H}_{2} \pm \mathrm{SE}\left(\mathrm{H}_{2}\right)$

$\mathrm{h}_{2} \pm \mathrm{SE}\left(\mathrm{h}_{2}\right)$

$\mathrm{E} \pm \mathrm{SE}(\mathrm{E})$

The parameters were tested for their significance by t-test; the t-value which exceeded 1.96 was marked significant. The following parameters were also calculated:

$\left[\sqrt{ }\left(4 \mathrm{DH}_{1}\right)+\mathrm{F}\right] /\left[\sqrt{ }\left(4 \mathrm{DH}_{1}\right)-\mathrm{F}\right]=$ the relative proportion of dominant and recessive gene in the parents

$\mathrm{h}_{2} / \mathrm{H}_{2}=$ the number of genes which control the character and exhibit dominance.

$\sqrt{ }\left(\mathrm{H}_{1} / \mathrm{D}\right)=$ mean degree of dominance

$\mathrm{H}_{2} / 4 \mathrm{H}_{1}=$ Proportion of dominant genes with positive/negative effects.

Heritability in both narrow and broad, sense were estimated using $\mathrm{D}, \mathrm{H}_{1}, \mathrm{~F}$ and $\mathrm{E}$ components of genetic variation as outlined by Verhalen and Murray (1969) for $F_{2}$ population:

Narrow sense heritability $\left(\mathrm{h}^{2}\right)=$

$1 / 4 \mathrm{D}$

$$
1 / 4 \mathrm{D}+1 / 4 \mathrm{H}_{1}-1 / 4 \mathrm{~F}+\mathrm{E}
$$

\section{RESULTS}

A $5 \times 5$ half diallel population developed from five morphologically diverse parents was studied in the present investigation. Mean squares from simple analysis of variance, Hayman's ANOVA (modified by Jones 1965), genetic components variations are presented in Table 1 to 3 . Analysis of variance showed highly significant values for all the characters studied in case of parents, $\mathrm{F}_{1}$ 's and parents $v s$ $\mathrm{F}_{1}$ 's except days to first flowering, days to edible pod maturity, days to seed maturity, number of pods per inflorescence and edible pod length in parent's $v_{s} \mathrm{~F}_{1}$ 's (Table 1).

Hayman's Analysis (Graphical and Numerical Approach)

Days to first inflorescence appearance : It was found highly significant value for analysis of variance to determine days to first inflorescence appearance for all the item suggested by Hayman's and followed by Jones (1965) (Table 2). The regression line was merged 'Wr' axis above the point of origin in ' $\mathrm{Vr}-\mathrm{Wr}$ ' graph that indicated presence of partial dominance for controlling the character days to first inflorescence appearance (Figure 1a). Array point of five parents scattered all along the regression line in ' $\mathrm{Vr}-\mathrm{Wr}$ ' graph. 


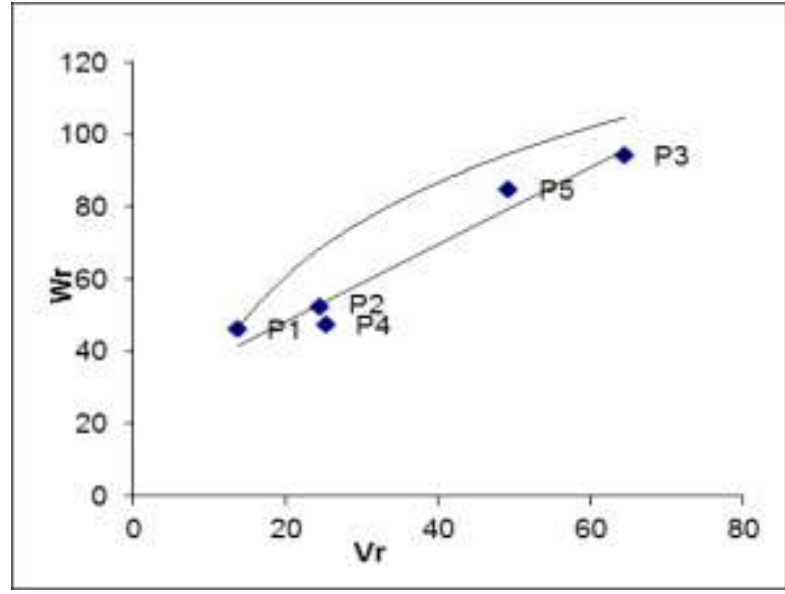

a

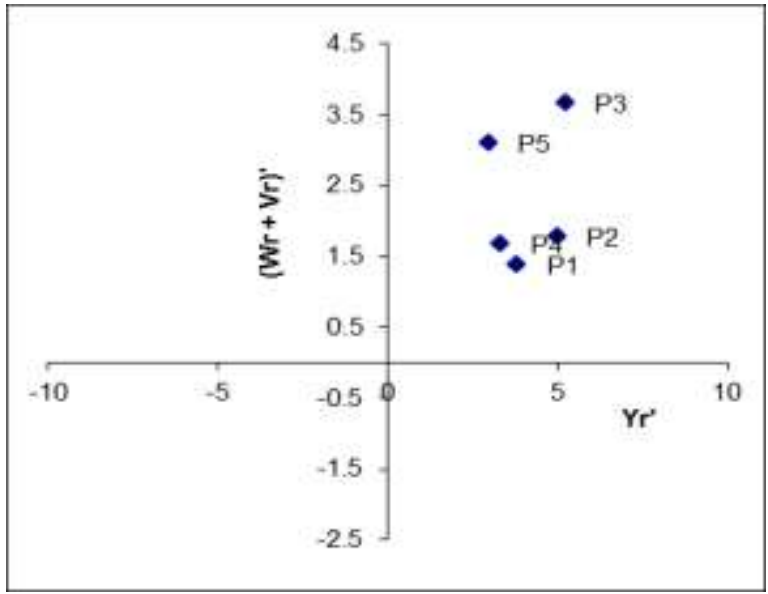

b

Figure 1. 'Vr-Wr' (a) and parental mean (b) graph for days to first inflorescence appearance in $5 \mathrm{x} 5$ half diallel population in lablab bean.

The consistency of dominance or recessive with positive or negative effects in opposition to parental mean score was determined in the $\mathrm{Yr}-(\mathrm{Wr}+\mathrm{Vr})^{\prime}$ graph (Figure 1b). Early inflorescence appearance was negatively associated with the direction of higher $\mathrm{Yr}$ ' value. It was found that $\mathrm{P}_{5}$ possessed the early appearance inflorescence among the parents. The highly significant value was observed for components D, $\mathrm{H}_{1}, \mathrm{H}_{2}$ and $\mathrm{F}$ for days to first inflorescence appearance (Table 3). $\mathrm{H}_{2}$ and $\mathrm{h}_{2}$ indicated dominance with asymmetry and higher degree of dominance with negative effects, respectively. 
Table 1. Analysis of variance for 13 different characters in a five parental half diallel population in lablab bean

\begin{tabular}{|c|c|c|c|c|c|c|c|c|c|c|c|c|c|c|}
\hline $\begin{array}{l}\text { Sources } \\
\text { of } \\
\text { Variation }\end{array}$ & df & DFI & DFF & DPM & DSM & NIP & NNI & NPI & NPP & EPL & EPB & EPW & HSW & PYP \\
\hline Rep. & 2 & $4.48^{\mathrm{NS}}$ & $8.99^{\mathrm{NS}}$ & $30.63^{\mathrm{NS}}$ & $40.49^{\mathrm{NS}}$ & $54.24^{\mathrm{NS}}$ & $0.96^{\mathrm{NS}}$ & $0.11^{\mathrm{NS}}$ & $3220.47^{\text {NS }}$ & $1.09^{\mathrm{NS}}$ & $0.01^{\mathrm{NS}}$ & $0.01^{\mathrm{NS}}$ & $0.07^{\mathrm{NS}}$ & $0.57^{\mathrm{NS}}$ \\
\hline Genotype & 14 & $207.60 * *$ & $680.24 * *$ & $1017.98 * *$ & $1316.06^{* *}$ & $=4402.79 * *$ & $15.73 * *$ & $5.99 * *$ & $325508.72 * *$ & $* 12.34 * *$ & $1.25 * *$ & $16.83^{* *}$ & $163.37 * *$ & $34.89 * *$ \\
\hline $\mathrm{P}$ & 4 & $534.23 * *$ & $1512.35^{* *}$ & $2012.39 * *$ & $2687.65^{* *}$ & $947.65^{* *}$ & $35.07 * *$ & $11.76 * *$ & $263617.77 * *$ & $* 24.25 * *$ & $2.31 * *$ & $33.05 * *$ & $137.54 * *$ & $7.11^{* *}$ \\
\hline$F_{1}^{\prime} s$ & 9 & $84.17 * *$ & $379.36^{* *}$ & $685.14^{* *}$ & $852.47 * *$ & $4737.14 * *$ & $5.43 * *$ & $4.08 * *$ & $333332.74 * *$ & * $8.38 * *$ & $0.71 * *$ & $10.13 * *$ & $150.29 * *$ & $37.89 * *$ \\
\hline P vs F ${ }_{1}^{\prime}$ s & 1 & $11.99 * *$ & $59.62^{\mathrm{NS}}$ & $35.97^{\mathrm{NS}}$ & $2.01^{\mathrm{NS}}$ & $15106.18 * *$ & $31.06 * *$ & $0.10^{\mathrm{NS}}$ & $502656.40^{* *}$ & $0.26^{\mathrm{NS}}$ & $1.83 * *$ & $12.19 * *$ & $384.44 * *$ & $118.99 * *$ \\
\hline Error & 28 & 1.52 & 23.68 & 15.63 & 16.63 & 56.23 & 0.62 & 0.41 & 14156.78 & 1.51 & 0.01 & 0.36 & 0.19 & 1.74 \\
\hline
\end{tabular}

$* P>0.05 ; * * P>0.01 ; N S>$ non-significant

$\mathrm{DFA}=$ Days to first inflorescence, $\mathrm{DFF}=$ Days to first flowering, DPM= Days to Pod Maturity, DSM= Days to Seed Maturity, NIP= Number of inflorescence per plant, NNI= Number of node per inflorescence, NPI= Number of pods per inflorescence, NPP= Number of pods per plant, EPL= Edible pod length $(\mathrm{cm}), \mathrm{EPB}=$ Edible pod breadth $(\mathrm{cm}), \mathrm{EPW}=$ Edible pod weight $(\mathrm{g}), \mathrm{HSW}=$ Hundred seed weight $(\mathrm{g}), \mathrm{PYP}=$ Pod yield per plant $(\mathrm{kg})$. 
Table 2. Hayman's ANOVA (modified by Morley Jones) for 13 different characters in a five parental half diallel population in lablab bean

\begin{tabular}{|c|c|c|c|c|c|c|c|c|c|c|c|c|c|}
\hline $\begin{array}{l}\text { Sources of } \\
\text { Variation }\end{array}$ & $\mathbf{f}_{\text {df }}$ & DFI & DFF & DPM & DSM & NIP & NNI & NPI & NPP & EPB & EPW & HSW & PYP \\
\hline A & 4 & $209.69 * *$ & $684.04 * *$ & $826.44 * *$ & $1351.02 * *$ & $1803.77 * *$ & $* 12.57 * *$ & $3.76^{* *}$ & $203452.53 * * 12.70 * *$ & $1.22 * *$ & $16.43^{* *}$ & $56.09 * *$ & $14.39 * *$ \\
\hline $\mathrm{B}$ & 10 & $107.59 * *$ & $358.69 * *$ & $561.99 * *$ & $665.78 * *$ & $3267.51 * *$ & $* 9.50 * *$ & $3.45^{* *}$ & $204661.64 * * 6.36 * *$ & $0.65 * *$ & $8.56^{* *}$ & $106.57 * *$ & $23.54 * *$ \\
\hline$b_{1}$ & 1 & $4.00 * *$ & $19.87^{\mathrm{NS}}$ & $11.99^{\mathrm{NS}}$ & $0.67^{\mathrm{NS}}$ & $5035.39 * *$ & $* 10.35 * *$ & $0.03^{\mathrm{NS}}$ & $167552.13 * * 0.09^{\mathrm{NS}}$ & $0.61 * *$ & $4.06 * *$ & $128.15^{* *}$ & $39.66^{* *}$ \\
\hline $\mathrm{b}_{2}$ & 4 & $25.78 * *$ & $98.15^{* *}$ & $214.33 * *$ & $128.88 * *$ & $1773.33 * *$ & $* 2.81 * *$ & $1.63 * *$ & $90005.88 * * 1.49 *$ & $0.03 * *$ & $0.83 * *$ & $43.79 * *$ & $8.22 * *$ \\
\hline$b_{3}$ & 5 & $193.76^{* *}$ & $634.89 * *$ & $950.12 * *$ & $1228.32 * *$ & $4109.27 * *$ & * $14.68 * *$ & $5.59 * *$ & $303808.14 * * 11.51 * *$ & $1.16^{* *}$ & $15.71 * *$ & $152.48 * *$ & $32.56^{* *}$ \\
\hline Error & 28 & 0.51 & 7.89 & 5.21 & 5.54 & 18.74 & 0.21 & 0.14 & 4718.93 & 0.0036 & 0.12 & 0.06 & 0.58 \\
\hline
\end{tabular}

$* P>0.05 ; * * P>0.01 ; N S>$ non-significant

$\mathrm{DFA}=$ Days to first inflorescence, $\mathrm{DFF}=$ Days to first flowering, $\mathrm{DPM}=$ Days to Pod Maturity, DSM= Days to Seed Maturity, NIP= Number of inflorescence per plant, NNI= Number of node per inflorescence, NPI= Number of pods per inflorescence, NPP= Number of pods per plant, EPL= Edible pod length $(\mathrm{cm}), \mathrm{EPB}=$ Edible pod breadth $(\mathrm{cm}), \mathrm{EPW}=$ Edible pod weight $(\mathrm{g}), \mathrm{HSW}=$ Hundred seed weight $(\mathrm{g}), \mathrm{PYP}=\mathrm{Pod}$ yield per plant $(\mathrm{kg})$. 
As dominance gene action was predominant for this trait which may helps to get transgressive segregant to develop pureline variety. The significant value of component $\mathrm{E}\left(0.29^{* *}\right)$ also revealed the essential contribution of environment for this character. Similar result also reported by Sen et al (2018).

Days to first flowering: The analysis of variance showed eminent significant value for all the items except ' $b_{1}$ ' for days to first flowering (Table 2). The value ' $b_{1}$ ' was found non-significant for this trait. The item ' $b_{2}$ ' and dominance deviation was also observed significant value of item ' $b_{3}$ ' for expressing this character. The presence of partial dominance was reported for controlling the character days to first flowering as the regression line intersected the ' $\mathrm{Wr}$ ' axis above the point of origin (Figure 2a). It was clearly visible that $\mathrm{P}_{4}$ located near the point of origin and in contrast, the parent $\mathrm{P}_{3}$ located far from the origin. The array points for this character were scattered all along the ' $\mathrm{Vr}-\mathrm{Wr}$ ' graph.
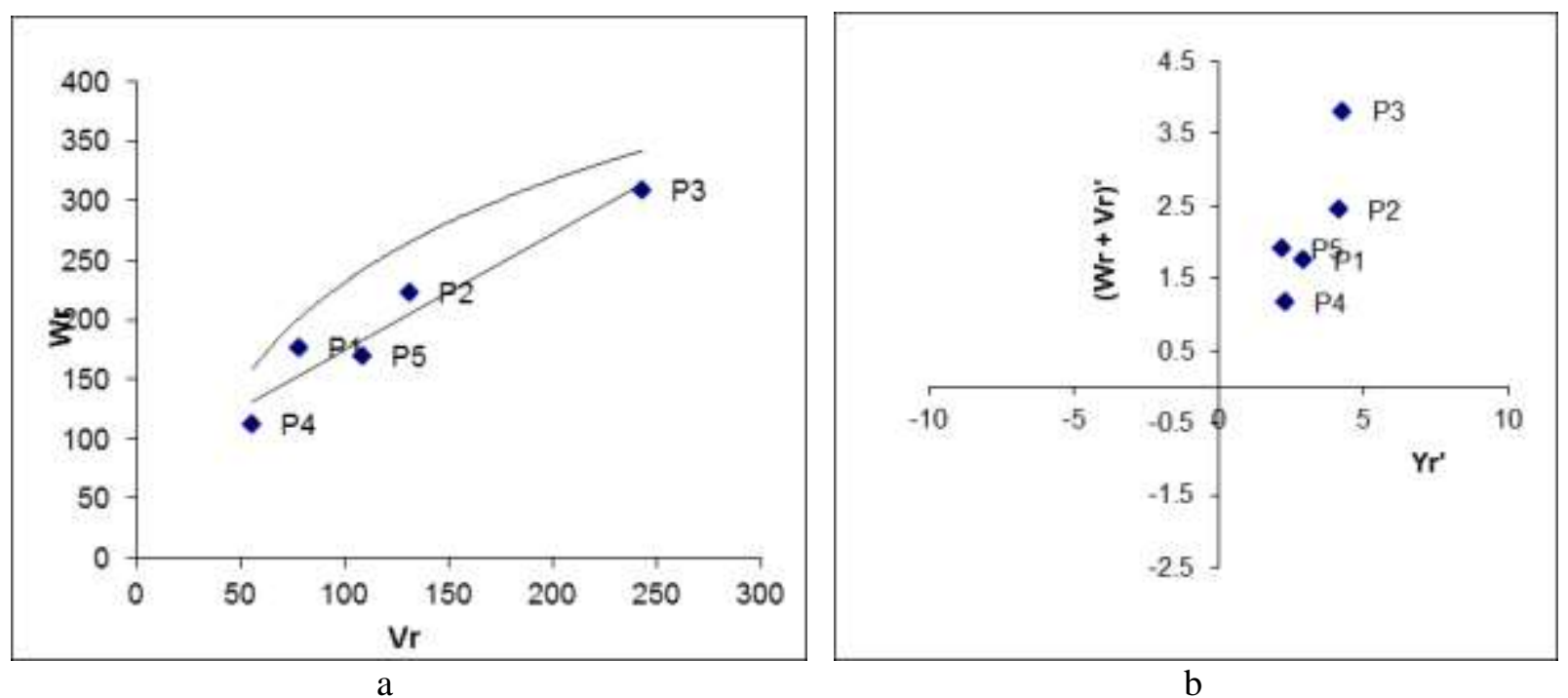

Figure 2. ' $\mathrm{Vr}-\mathrm{Wr}$ ' (a) and parental mean (b) graph for days to first flowering in 5 x 5 half diallel populations in lablab bean.

The Yr'-(Wr+Vr)' graph showed relative distribution of five parental score that indicated predominance of recessive alleles with positive effect (Figure $2 b$ ). The parent $\mathrm{P}_{2}$ and $\mathrm{P}_{3}$ showed higher $\mathrm{Yr}^{\prime}$ values and parent $\mathrm{P}_{5}$ has lower values for this character. 
Table 3. Estimation of different genetic components of variation and ratios for 13 different characters in a five parental half diallel population in lablab bean

\begin{tabular}{|c|c|c|c|c|c|c|c|c|c|c|c|c|c|}
\hline $\begin{array}{l}\text { Sources of } \\
\text { Variation }\end{array}$ & DFI & DFF & DPM & DSM & NIP & NNI & NPI & NPP & EPL & EPB & EPW & HSW & PYP \\
\hline $\mathrm{D}$ & $117.79 * *$ & $500.33 * *$ & $668.03 * *$ & $892.85^{* *}$ & $315.53^{* *}$ & $11.58 * *$ & $3.85 * *$ & $85634.64 * *$ & $7.84 * *$ & $0.77 * *$ & $10.96 * *$ & $45.82 * *$ & $2.09 * *$ \\
\hline $\mathrm{F}$ & $96.68 * *$ & $212.88 * *$ & $403.23 * *$ & $247.10^{* *}$ & $64.59^{\mathrm{NS}}$ & $7.87 * *$ & $3.38 * *$ & $11577.59 *$ & $1.76 * *$ & $0.11 * *$ & $2.71 * *$ & $45.55 * *$ & $-3.59 * *$ \\
\hline $\mathrm{H}_{1}$ & $488.05^{* *}$ & $1316.64 * *$ & $1875.11 * *$ & $2213.79 * *$ & $766.25^{* *}$ & $33.43^{* *}$ & $11.91 * *$ & $201764.16^{* *}$ & $19.20 * *$ & $1.80 * *$ & $26.87 * *$ & $146.37 * *$ & $1.24^{\mathrm{NS}}$ \\
\hline $\mathrm{H}_{2}$ & $-428.71 * *$ & $-1126.59 * *$ & $-1234.69 * *$ & $-1886.47 * *$ & $4355.98 * *$ & $-25.33^{* *}$ & $-6.47 * *$ & $75627.29 * *$ & $-17.10^{* *}$ & $-1.53 * *$ & $-22.35^{* *}$ & $63.97 * *$ & $36.21 * *$ \\
\hline $\mathrm{h}_{2}$ & $-3.69 * *$ & $-10.23^{* *}$ & $4.30^{\mathrm{NS}}$ & $-3.38^{\mathrm{NS}}$ & $118.39 *$ & $5.57 * *$ & $-0.37 * *$ & $-714.85^{\mathrm{NS}}$ & $0.35 * *$ & $1.37 * *$ & $3.50 * *$ & $19.82 * *$ & $10.86 * *$ \\
\hline $\mathrm{E}$ & $0.29 * *$ & $3.78 * *$ & $2.77^{\mathrm{NS}}$ & $3.04 *$ & $9.35^{\mathrm{NS}}$ & $0.11^{* *}$ & $0.07 * *$ & $2237.95 *$ & $0.25 * *$ & $0.002 * *$ & $0.06 * *$ & $0.03^{\mathrm{NS}}$ & $0.28 *$ \\
\hline$\left(\mathrm{H}_{1} / \mathrm{D}\right)^{0.5}$ & 1.66 & 1.62 & 1.68 & 1.57 & 1.56 & 1.70 & 1.76 & 1.53 & 1.57 & 1.53 & 1.57 & 1.79 & 0.77 \\
\hline $\mathrm{H}_{2} / 4 \mathrm{H}_{1}$ & -0.22 & -0.21 & -0.16 & -0.21 & 1.42 & -0.19 & -0.14 & 0.09 & -0.22 & -0.21 & -0.21 & 0.11 & 7.31 \\
\hline $\mathrm{KD} / \mathrm{KR}$ & -1.65 & -4.94 & -2.11 & -4.95 & 2.23 & -2.87 & -3.19 & 1.75 & 2.36 & 157.74 & -19.01 & -1.20 & -0.51 \\
\hline $\mathrm{h}_{2} / \mathrm{H}_{2}$ & 0.01 & 0.01 & -0.003 & 0.002 & 0.03 & -0.22 & 0.06 & -0.01 & -0.02 & -0.89 & -0.16 & 0.31 & 0.30 \\
\hline$h_{n}^{2}$ & 0.31 & 0.30 & 0.31 & 0.31 & 0.29 & 0.30 & 0.30 & 0.30 & 0.29 & 0.31 & 0.31 & 0.31 & 0.26 \\
\hline
\end{tabular}

$* P>0.05 ; * * P>0.01 ; N S>$ non-significant

$\mathrm{DFA}=$ Days to first inflorescence, $\mathrm{DFF}=$ Days to first flowering, DPM= Days to Pod Maturity, DSM= Days to Seed Maturity, NIP= Number of inflorescence per plant, $\mathrm{NNI}=$ Number of node per inflorescence, $\mathrm{NPI}=$ Number of pods per inflorescence, $\mathrm{NPP}=\mathrm{Number}$ of pods per plant, EPL= Edible pod length $(\mathrm{cm}), \mathrm{EPB}=$ Edible pod breadth $(\mathrm{cm}), \mathrm{EPW}=$ Edible pod weight $(\mathrm{g}), \mathrm{HSW}=$ Hundred seed weight $(\mathrm{g}), \mathrm{PYP}=$ Pod yield per plant $(\mathrm{kg})$. 
Positive and significant measures was found for components $\mathrm{D}, \mathrm{H}_{1}, \mathrm{~F}$ and $\mathrm{E}$ for days to first flowering in lablab bean (Table 3). On the other hand, negative significant measure was found for components $\mathrm{H}_{2}\left(-1126.59^{* *}\right)$ and $\mathrm{h}_{2}\left(-3.69^{* *}\right)$.

Days to first edible pod maturity: The significant value was found for item ' $a$ ', ' $b$ ', ' $b_{2}$ ' and ' $b_{3}$ ' for the character of days to first edible pod maturity (Table 2). The non-significant value was found for the item ' $b_{1}$ '. The regression line in ' $\mathrm{Vr}-\mathrm{Wr}$ ' graph touches ' $\mathrm{Wr}$ ' axis far above the point of origin (Figure $3 \mathrm{a}$ ) for days to edible pod maturity. The array points $\mathrm{P}_{3}$ and $\mathrm{P}_{1}$ situated far from the origin. The 'Vr-Wr' graph also showed scattered array points along the regression line.
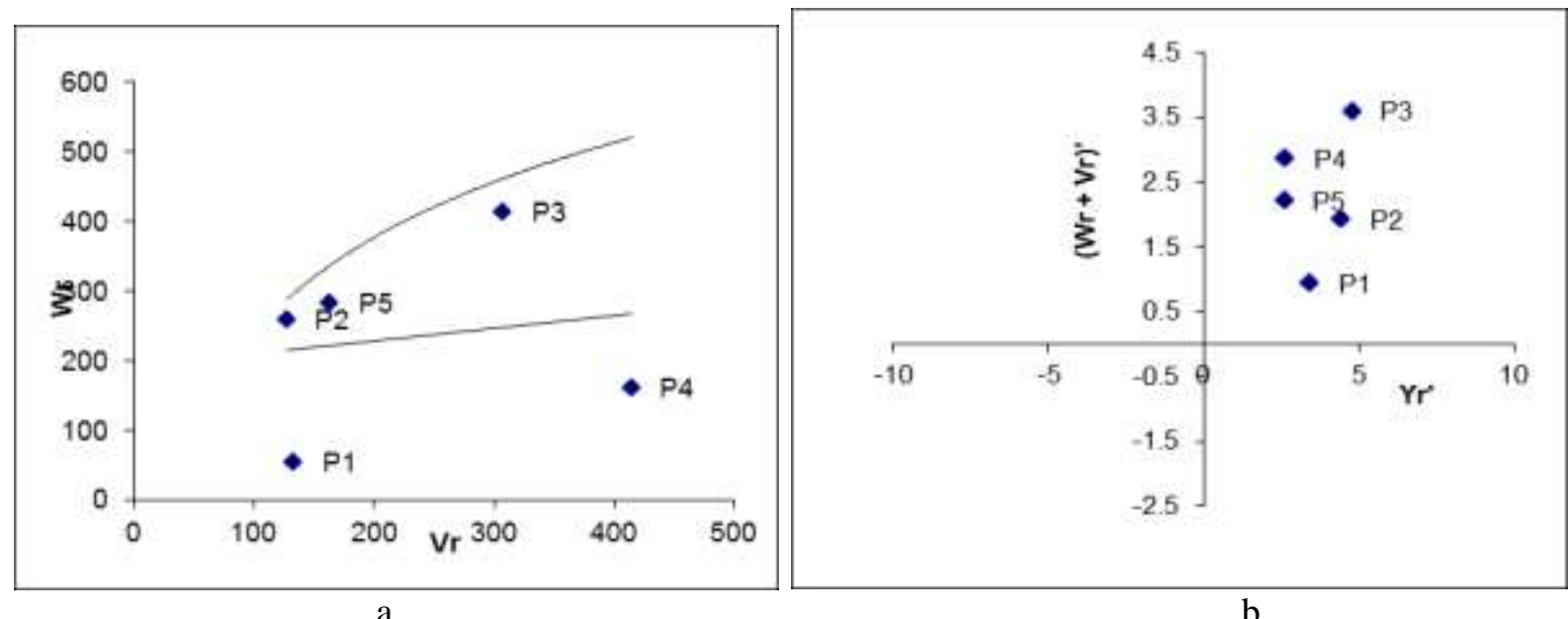

Figure 3. ' $\mathrm{Vr}-\mathrm{Wr}$ ' (a) and parental mean (b) graph for days to edible pod maturity in $5 \mathrm{x} 5$ half diallel populations in lablab bean.

The predominance of recessive alleles with positive effect was found for all the five parental score for controlling days to edible pod maturity in $\mathrm{Yr}^{\prime}-(\mathrm{Wr}+\mathrm{Vr})$ ' graph (Figure $\left.3 b\right)$. It was found that both $\mathrm{P}_{4}$ and $\mathrm{P}_{5}$ were closely located having lower ' $\mathrm{Yr}$ ' value than rest of the parental $\left(\mathrm{P}_{1}, \mathrm{P}_{2}\right.$ and $\left.\mathrm{P}_{3}\right)$ for edible pod maturity in lablab bean. The significant value was found for the components $\mathrm{D}, \mathrm{H}_{1}$ and $\mathrm{F}$ for days to edible pod maturity (Table 3). The components $h_{2}$ and $E$ found non-significant value. The negative value for $\mathrm{H}_{2} / 4 \mathrm{H}_{1}(0.16)$ was far from 0.25 .

Days to seed maturity: The analysis of variance showed significant value for all the items except ' $b_{1}$ ' for days to seed maturity (Table 2 ). Again, item ' $b_{2}$ ' and ' $b_{3}$ ' conveyed asymmetrical dominance and part of dominance deviation (which were not related to item ' $b_{1}$ ' and ' $b_{2}$ '), respectively. The item ' $b_{1}$ ' was found non-significant for days to seed maturity. The regression line touches ' $\mathrm{Wr}$ ' axis above the point of origin in ' $\mathrm{Vr}-\mathrm{Wr}$ ' graph that indicated presence of partial dominance for controlling days to seed maturity (Figure 4a). The parent $\mathrm{P}_{2}$ situated near to origin whereas $\mathrm{P}_{3}$ situated far away from origin. The $\mathrm{Yr}^{\prime}-(\mathrm{Wr}+\mathrm{Vr})^{\prime}$ graph showed relative distribution of five parental score that indicated predominance of recessive alleles with positive effect (Figire $4 \mathrm{~b}$ ). It was found that the parent $\mathrm{P}_{2}$ had the lowest value in $(\mathrm{Wr}+\mathrm{Vr})$ ' axis and $\mathrm{P}_{3}$ had higher value. It was observed that both $\mathrm{P}_{4}$ and $\mathrm{P}_{5}$ were closely located with lower $\mathrm{Yr}^{\prime}$ value and the parents $\mathrm{P}_{4}$ and $\mathrm{P}_{5}$ had higher value for days to seed maturity. 


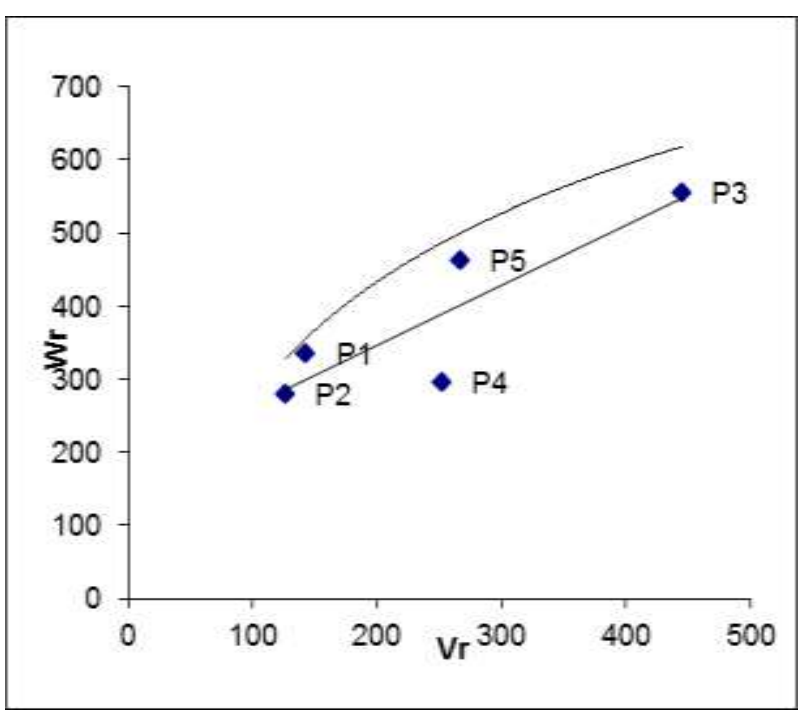

a

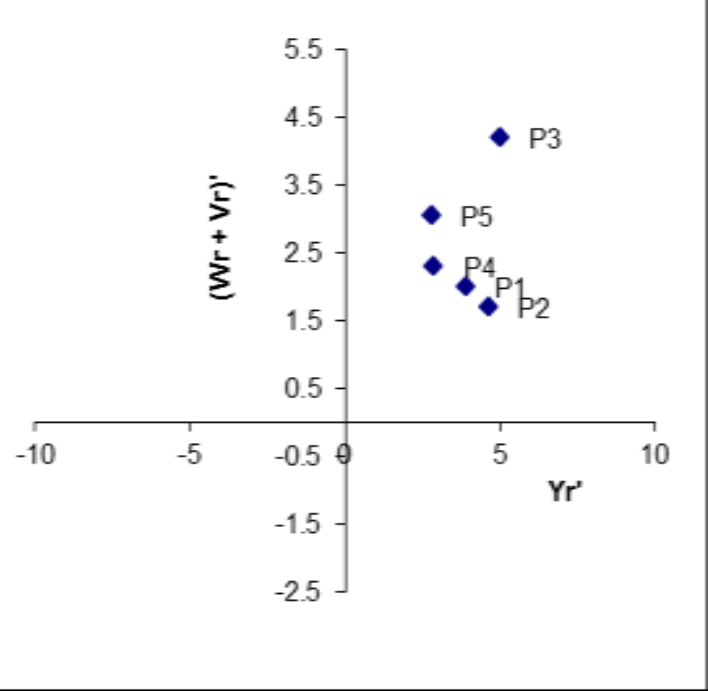

b

Figure 4. 'Vr-Wr' (a) and parental mean (b) graph for days to seed maturity in $5 \mathrm{x} 5$ half diallel populations in lablab bean.

Significant positive value was found for the components $\mathrm{D}, \mathrm{H}_{1}, \mathrm{~F}$ and $\mathrm{E}$ for days to seed maturity (Table 3). In contrast negative significant measure was found for components $\mathrm{H}_{2}$.

Number of inflorescences per plant: The significant value of item ' $a$ ' and ' $b$ ' ensured the presence of both additive and dominance components (Table 2). The item ' $b_{1}$ ', ' $b_{2}$ ' and ' $b_{3}$ ' was found significant for number of inflorescence per plant. It was found that the regression line intersected the 'Wr' axis below the point of origin in ' $\mathrm{Vr}-\mathrm{Wr}$ ' graph (Figure 5a). The scattered distribution was observed for the parental arrays all along the regression line.

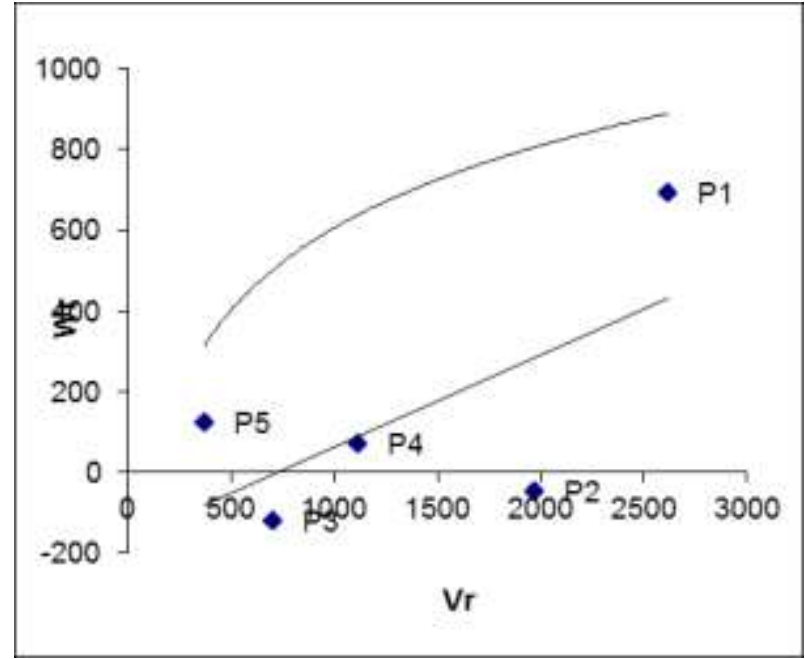

a

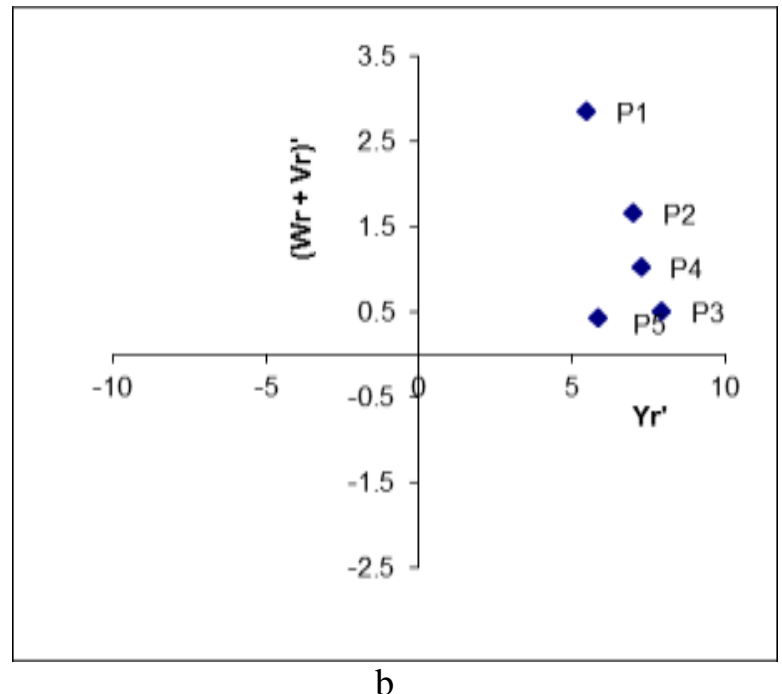

b

Figure 5. 'Vr-Wr' (a) and parental mean (b) graph for number of inflorescences per plant in $5 \mathrm{x} 5$ half diallel populations in lablab bean.

The parental graph clearly showed that all the five parents had predominance of recessive alleles with positive effects for number of inflorescences per plant (Figure 5b). The parent $\mathrm{P}_{3}$ gave the highest ' $\mathrm{Yr}$ ' value for number of inflorescences per plant. The positive significant value was observed for components D, $\mathrm{H}_{1}$ and $\mathrm{H}_{2}$ for number of inflorescence per plant (Table 3). The non-significant valu was observed for the component $\mathrm{E}$. 
Number of nodes per inflorescence: The significant value of item ' $a$ ' and ' $b$ ' revealed the presence of both additive and dominance components, respectively (Table 2). The $\mathrm{Vr}$ - $\mathrm{Wr}$ graph for number of nodes per inflorescence showed that the regression line intersected the ' $\mathrm{Wr}$ ' axis slightly above the point of origin (Figure 6a). The array points $\mathrm{P}_{4}$ and $\mathrm{P}_{5}$ located near the point of origin and in contrast, $\mathrm{P}_{1}$ located far from the origin. Array points were found distributed all along the regression line in the graph (Figure 6a).

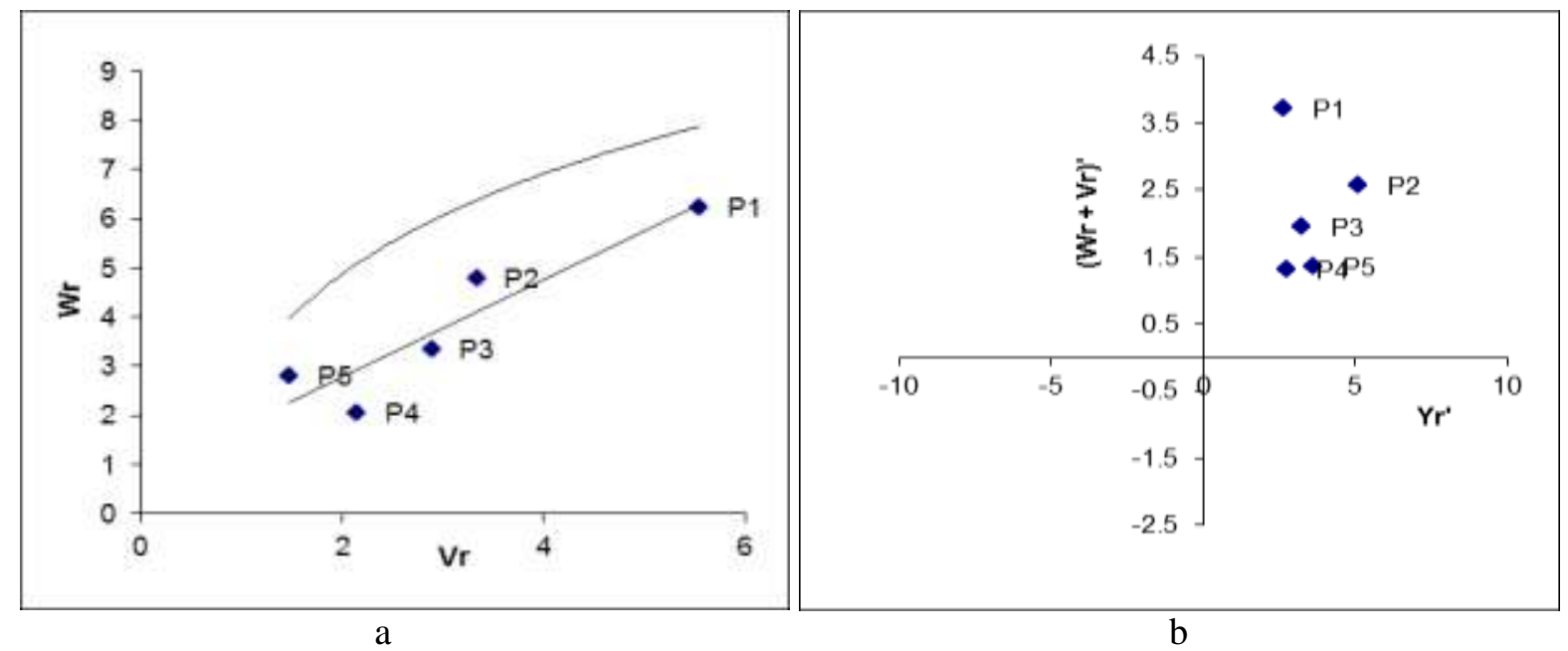

Figure 6. ' $\mathrm{Vr}-\mathrm{Wr}$ ' (a) and parental mean (b) graph for number of nodes per inflorescence in $5 \times 5$ half diallel populations in lablab bean.

The $\mathrm{Yr}^{\prime}-(\mathrm{Wr}+\mathrm{Vr})^{\prime}$ graph indicated predominance of recessive alleles with positive effect. The parent $\mathrm{P}_{2}$ showed the highest $\mathrm{Yr}^{\prime}$ value and the parent $\mathrm{P}_{5}$ gave the minimum $\mathrm{Yr}$ ' value for number of nodes per inflorescence. The positive significant measure was found for the components $\mathrm{D}, \mathrm{H}_{1}, \mathrm{~F}$ and $\mathrm{E}$ (Table 3). In contrast, negative significant measure was found for components $\mathrm{H}_{2}\left(-25.33^{* *}\right)$. Again, positive significant value was observed for component $\mathrm{h}_{2}$.

Number of pods per inflorescence: The analysis of variance showed significant value for all the items except ' $b_{1}$ ' for number of pods per inflorescence (Table 2). Non-significant value was found for the item ' $b_{1}$ ' for number of pods per inflorescence. The regression line intersected the $\mathrm{Wr}$ axis below the point of origin in the $\mathrm{Vr}-\mathrm{Wr}$ graph for the character of number of pods per inflorescence as (Figure 7a). Scattered distribution of array points was found all along the regression line. It was noticed that $\mathrm{P}_{1}$ having lower ' $\mathrm{Yr}$ ' value whether $\mathrm{P}_{2}$ had higher ' $\mathrm{Yr}$ ' measure. The highly significant value was observed for components $\mathrm{D}, \mathrm{H}_{1}$ and for number of pods per inflorescence (Table 3 ). The components $\mathrm{H}_{2}$ and $\mathrm{h}_{2}$ was found significant for this trait. The significant of component $\mathrm{E}$ also observed for this character.

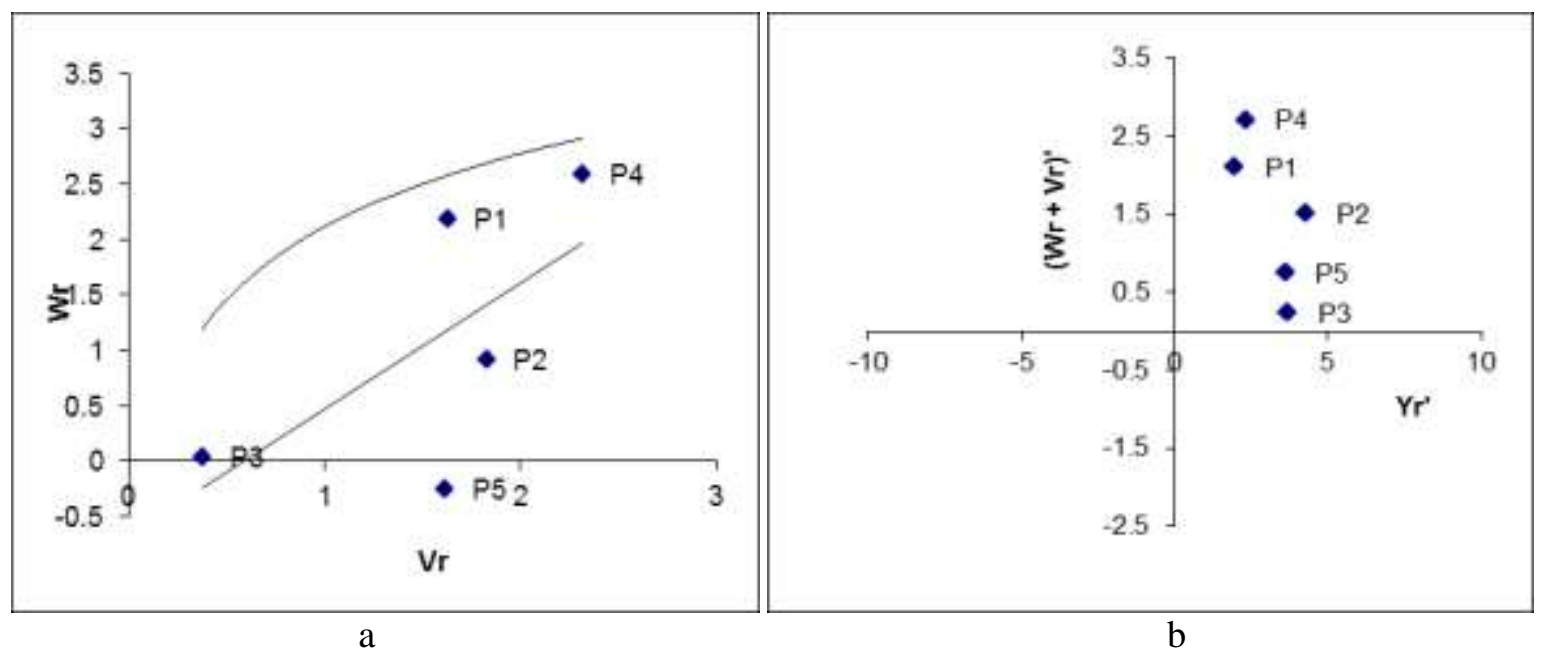

Figure 7. ' $\mathrm{Vr}-\mathrm{Wr}$ ' (a) and parental mean (b) graph for number of pods per inflorescence in $5 \mathrm{x} 5$ half diallel populations in lablab bean. 
Number of pods per plant: Highly significant value was found for mean sum square of number of pods per plant for all the items in Table 2. The item ' $b_{1}$ ', ' $b_{2}$ ' and ' $b_{3}$ ' was found significant. The regression line passed in ' $\mathrm{Wr}$ ' axis through the point of origin in ' $\mathrm{Vr}-\mathrm{Wr}$ ' graph for number of pods per plant (Figure 8a). The distribution of array point showed that parent $\mathrm{P}_{5}$ situated nearby the origin and on the other hand array point of $\mathrm{P}_{1}$ situated far away from origin. Array point of five parents scattered all along the regression line in ' $\mathrm{Vr}-\mathrm{Wr}$ ' graph. The $\mathrm{Yr}$ '- $(\mathrm{Wr}+\mathrm{Vr})$ ' graph showed relative distribution of five parental score (Figure 8b). It was observed that both $\mathrm{P}_{2}$ and $\mathrm{P}_{3}$ were closely located having higher $\mathrm{Yr}^{\prime}$ value for number of pods per plant than rest of the parental score. Significant positive value was observed for components $\mathrm{D}, \mathrm{H}_{1}, \mathrm{H}_{2}$ and $\mathrm{F}$. The component $\mathrm{E}$ was found significant for this character.
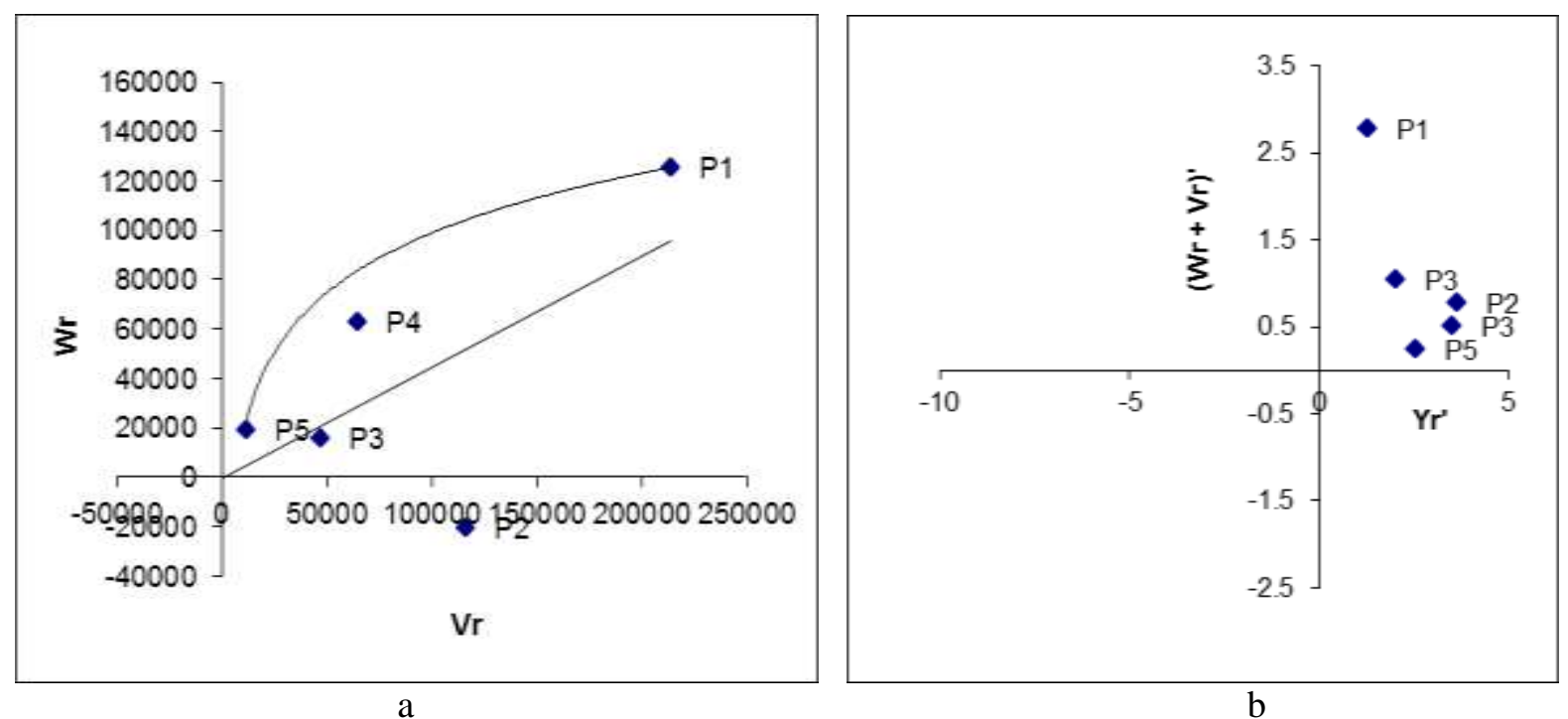

Figure 8. 'Vr-Wr' (a) and parental mean (b) graph for number of pods per plant in 5 x 5 half-diallel populations in lablab bean.

Edible pod length $(\mathrm{cm})$ : The significant value was found for item ' $a$ ', ' $b$ ', ' $\mathrm{b}_{2}$ ' and ' $\mathrm{b}_{3}$ ' for the character edible pod length (Table 2). The non-significant value was observed for item ' $b_{1}$ '. The regression line intersected the ' $\mathrm{Wr}$ ' axis far above the point of origin in ' $\mathrm{Vr}-\mathrm{Wr}$ ' graph (Figure 9a). Scattered distribution was observed for the array points all along the regression line. The parental graph clearly showed that all the five parents had predominance of recessive alleles with positive effects for edible pod legth (Figure 9b). Edible pod length was positively associated with the direction of higher $\mathrm{Yr}^{\prime}$ value. The parent $\mathrm{P}_{2}$ possessed the highest $\mathrm{Yr}^{\prime}$ value for edible pod length. It was found positive significant measure for components $\mathrm{D}, \mathrm{H}_{1}, \mathrm{~F}$ and $\mathrm{E}$ for edible pod length in lablab bean (Table 3). In contrast, negative significant measure was found for components $\mathrm{H}_{2}$. Again, positive and significant value was observed for component $\mathrm{h}_{2}$. 


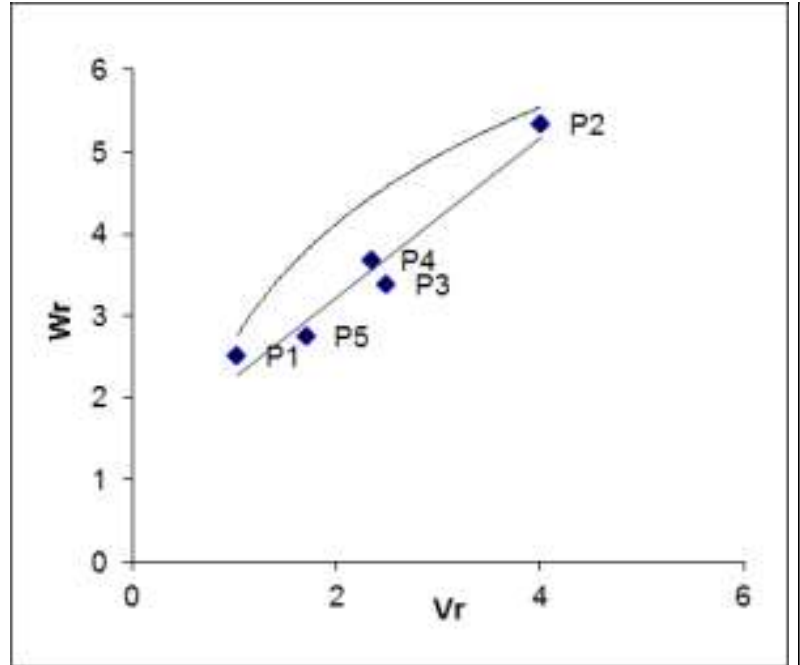

a

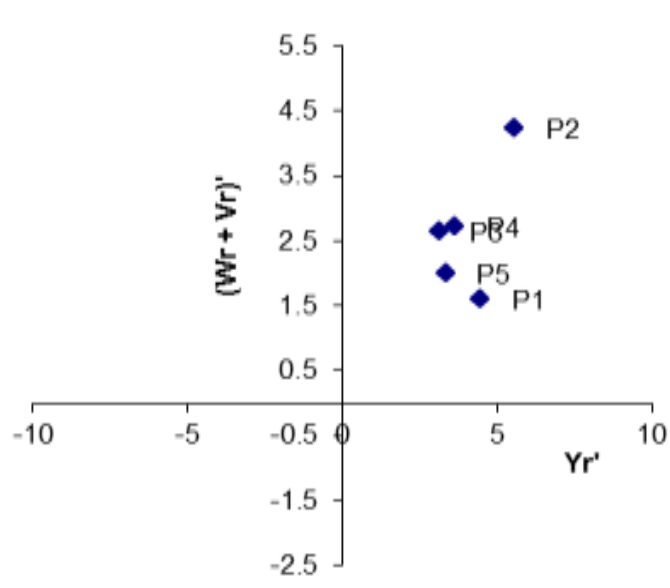

b

Figure 9. 'Vr-Wr' (a) and parental mean (b) graph for edible pod length in $5 \mathrm{x} 5$ half diallel populations in lablab bean.

Edible pod breadth (cm): The significant value of item ' $a$ ' and ' $b$ ' revealed the presence of both additive and dominance components, respectively for the expression of edible pod breadth (Table 2). The significant value was found for the item ' $b_{1}$ ', ' $b_{2}$ ' and ' $b_{3}$ ' for this character.

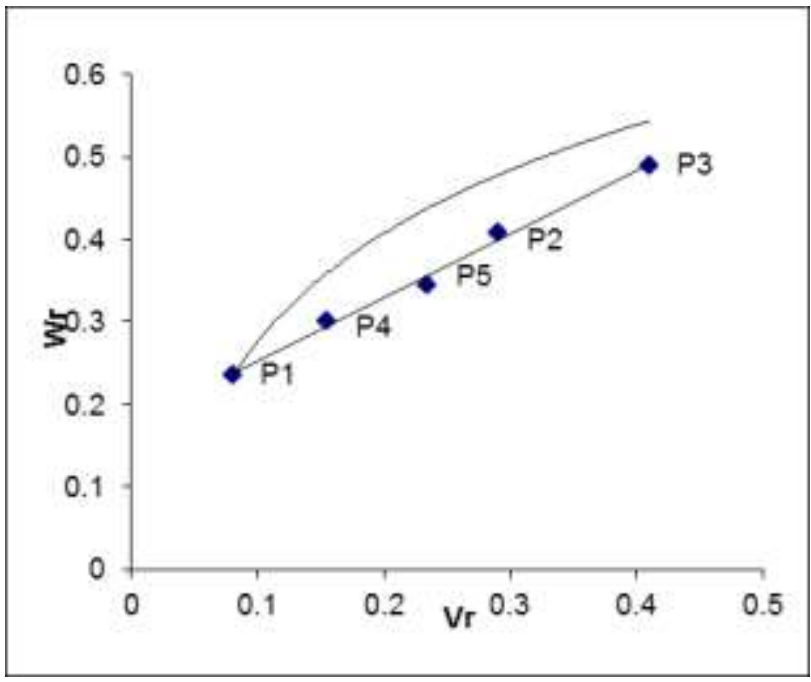

a

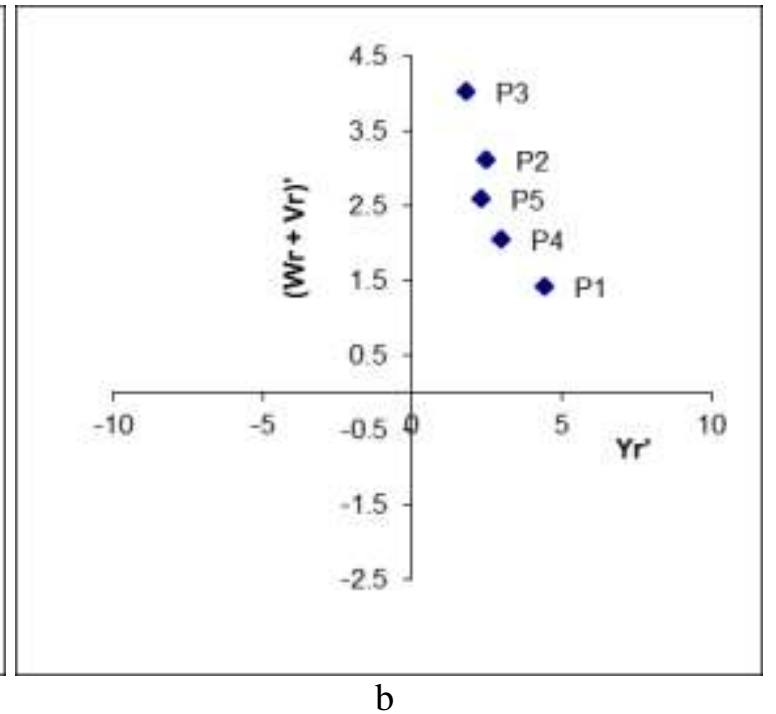

Figure 10. 'Vr-Wr' (a) and parental mean (b) graph for edible pod breadth in 5 x 5 half diallel populations in lablab bean.

VR-Wr graph for edible pod breadth showed that the regression line intersected the ' $\mathrm{Wr}$ ' axis above the point of origin (Figure 10a). The array point of parent, $\mathrm{P}_{3}$ located far away from the origin and $\mathrm{P}_{1}$ located near the origin. The $\mathrm{Yr}^{\prime}-(\mathrm{Wr}+\mathrm{Vr})^{\prime}$ graph showed relative distribution of five parental score (Figure 11b). It was easily notified the presence of higher $\mathrm{Yr}^{\prime}$ measure for $\mathrm{P}_{1}$ parental score for edible pod breadth. The positive significant measure was identified for components $\mathrm{D}, \mathrm{H}_{1}, \mathrm{~F}$ and $\mathrm{E}$ (Table $3)$. The negative significant measure was found for components $\mathrm{H}_{2}$. The value of $\mathrm{KD} / \mathrm{KR}$ (157.74) was very high for edible pod breadth.

Edible pod weight (g): Edible pod weight showed the significant value for all the items found in Table 2. It was revealed the meaningful presence of additive, dominance, asymmetrical distribution of dominance, unidirectional distribution of dominance and part of dominance deviation for expressing this character in positive direction. 
From the $\mathrm{Vr}-\mathrm{Wr}$ graph, it was revealed the presence of partial dominance for expressing the character edible pod weight as the regression line touched the 'Wr' axis above the point of origin (Figure 11a). Here, it could be easily identified that none of the parents located near the origin. Thus parents possessed negligible amount of dominant alleles. Majority of the array points situated at the middle part of the ' $\mathrm{Vr}-\mathrm{Wr}$ ' graph that suggested the parents contain equal proportion of dominant and recessive alleles. The parent $\mathrm{P}_{5}$ possessed maximum frequency of recessive alleles among the parent as it located far away from the origin.
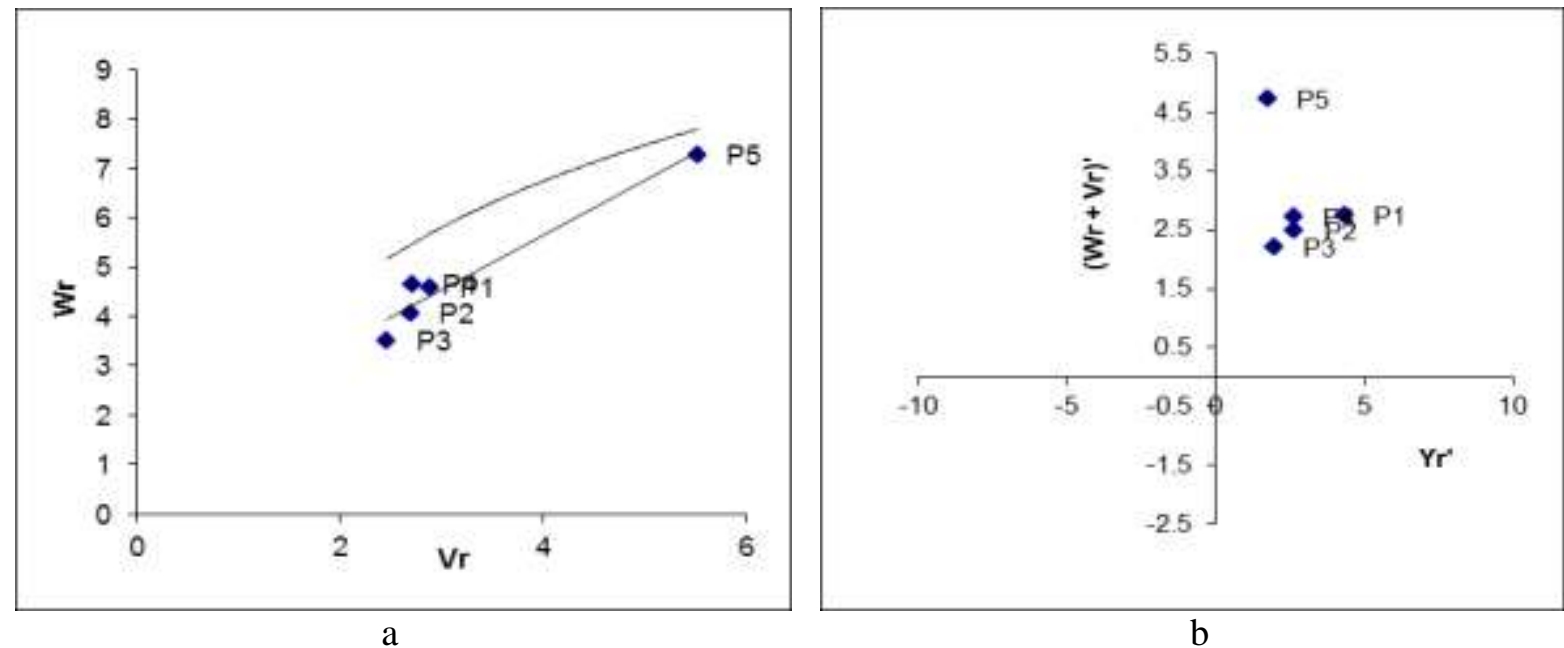

Figure 11. ' $\mathrm{Vr}-\mathrm{Wr}$ ' (a) and parental mean (b) graph for edible pod weight in $5 \times 5$ half diallel populations in lablab bean.

Edible pod weight (g): Edible pod weight showed the significant value for all the items found in Table 2. It was revealed the meaningful presence of additive, dominance, asymmetrical distribution of dominance, unidirectional distribution of dominance and part of dominance deviation for expressing this character in positive direction.

From the $\mathrm{Vr}-\mathrm{Wr}$ graph, it was revealed the presence of partial dominance for expressing the character edible pod weight as the regression line touched the 'Wr' axis above the point of origin (Figure 11a). Here, it could be easily identified that none of the parents located near the origin. Thus parents possessed negligible amount of dominant alleles. Majority of the array points situated at the middle part of the ' $\mathrm{Vr}-\mathrm{Wr}$ ' graph that suggested the parents contain equal proportion of dominant and recessive alleles. The parent $P_{5}$ possessed maximum frequency of recessive alleles among the parent as it located far away from the origin. The preponderance of recessive alleles with positive effect was found for all the five parental score for controlling this character in $Y^{\prime}-(\mathrm{Wr}+\mathrm{Vr})^{\prime}$ graph (Figure 11b). It was clearly presented that $\mathrm{P}_{1}$ located having higher $\mathrm{Yr}^{\prime}$ score that indicated the possibility of obtaining maximum pod weight from $\mathrm{P}_{1}$.

It was found positive significant measure for components $\mathrm{D}, \mathrm{H}_{1}, \mathrm{~F}$ and $\mathrm{E}$ that indicated the importance of additive, dominance, interaction of additive and dominance and environment for expressing pod weight in lablab bean (Table 3). Again, negative significant measure was found for components $\mathrm{H}_{2}$ that suggested the dominance with asymmetry in negative direction. The positive significant value was observed for component $\mathrm{h}_{2}$ that indicated higher degree of dominance in positive effects.

Hundreds seed weight (g): It was found highly significant value for analysis of variance for expressing hundred seed weight for all the items (Table 2). The significant value of item ' $a$ ' and ' $b$ ' was found significant. Item ' $b_{1}$ ' was also found significant. Asymmetric distribution of dominance and part of dominance deviation were suggested from item ' $b_{2}$ ' and ' $b_{3}$ ', respectively. In $\mathrm{Vr}-\mathrm{Wr}$ ' graph the regression line intersected the ' $\mathrm{Wr}$ ' axis below the point of origin for hundred seed weight (Figure 12a). The array point of the parent $\mathrm{P}_{2}$ located far away from the origin and $\mathrm{P}_{1}$ located in near the origin. Array point of five parents was scattered all along the regression line in ' $\mathrm{Vr}-\mathrm{Wr}$ ' graph for hundred seed weight. 


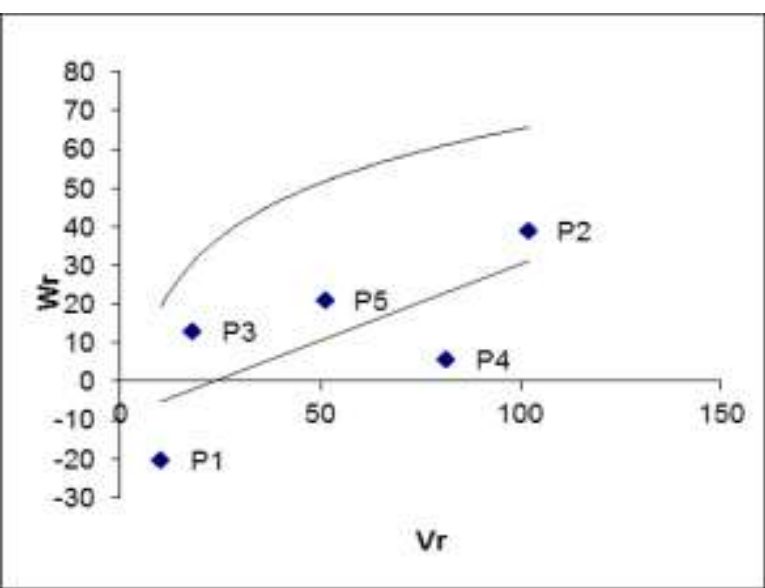

a

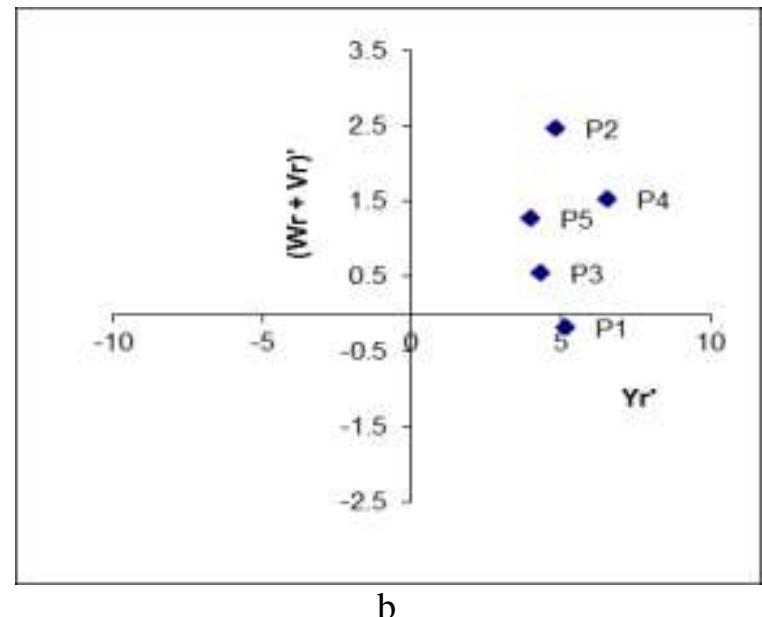

Figure 12. 'Vr-Wr' (a) and parental mean (b) graph for hundred seed weight in $5 \mathrm{x} 5$ half diallel populations in lablab bean.

The $\mathrm{Yr}^{\prime}-(\mathrm{Wr}+\mathrm{Vr})^{\prime}$ graph showed the distribution of $\mathrm{P}_{1}$ parent had the negative $(\mathrm{Wr}+\mathrm{Vr})^{\prime}$ and positive Yr' score (Figure 12b). In contrast, relative distribution was observed for the rest of the parental score. The positive significant value was observed for all components except E in Table 3. The nonsignificant value was observed for the component $\mathrm{E}$.

Pod yield per plant (kg): Analysis of variance showed higher significant value for pod yield per plant for all the items suggested by Hayman's and followed by Morley Jones (Table 2). The item 'a' and ' $b$ ' was reported to be significant for pod yield per plant. Significant value of item ' $b_{1}$ ', ' $b_{2}$ ' and ' $\mathrm{b}_{3}$ ' was also found significant. The regression line passed through ' $\mathrm{Wr}$ ' axis slightly above the point of origin in ' $\mathrm{Vr}-\mathrm{Wr}$ ' graph for expressing the eminent character pod yield per plant (Figure13a). The distribution of array point of $\mathrm{P}_{5}$ located nearby the origin and array point of $\mathrm{P}_{1}$ parent situated far away from origin. The scattered distribution of array points of five parents was observed all along the regression line in 'Vr-Wr' graph.
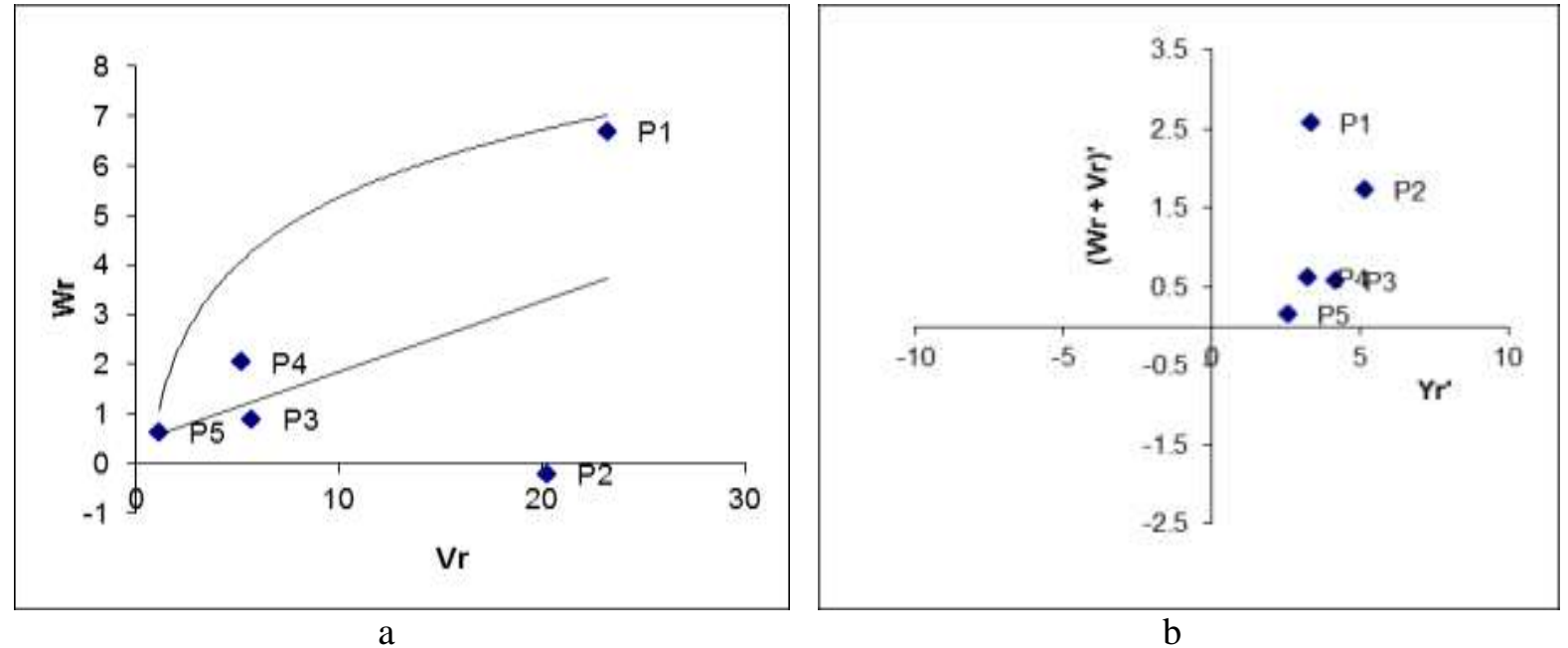

Figure 13. 'Vr-Wr' (a) and parental mean (b) graph for pod yield per plant in $5 \mathrm{x} 5$ half diallel populations in lablab bean.

The $\mathrm{Yr}^{\prime}-(\mathrm{Wr}+\mathrm{Vr})^{\prime}$ graph showed the distribution of parent had both the negative $(\mathrm{Wr}+\mathrm{Vr})^{\prime}$ and positive $\mathrm{Yr}^{\prime}$ score (Figure 13b). The parent $\mathrm{P}_{2}$ possessed the highest $\mathrm{Yr}^{\prime}$ value for pod yield per plant. The significant value was found for components $\mathrm{D}, \mathrm{H}_{2}$ and $\mathrm{h}_{2}$ (Table 3). The negative value for component $\mathrm{F}$ was observed for the character pod yield per plant in lablab bean. It was notified $\mathrm{KD} / \mathrm{KR}$ $(-0.59)$ value was lower than 1.0 with the heritability in narrow sense was $26 \%$. 


\section{DISCUSSION}

The result presented here provides information on gene action, combining ability and heterosis for plant and fruit characteristics of lablab bean genotypes. The significant test of item ' $a$ ' and ' $b$ ' reported that both additive and dominance gene action played a vital role for different genotype regulating days to first inflorescence appearance. Significant difference for item ' $b_{1}$ ' and ' $b_{2}$ ' indicated presence of unidirectional dominance (i.e. between parent and hybrid) and asymmetrical distribution of dominant gene for this character, respectively. The item ' $b_{3}$ ' was also highly significant that depicted the residual dominance deviations for this trait. The distribution of array point of $\mathrm{P}_{1}$ nearby the origin was supposed to contain maximum frequency of dominant alleles; array point of $\mathrm{P}_{3}$ parent situated far away from origin suggested presence of maximum frequency of recessive alleles among the five parents. Array point of five parents scattered all along the regression line in ' $\mathrm{Vr}-\mathrm{Wr}$ ' graph suggested genetic diversity among the parents for days to first inflorescence appearance. It was clearly observed that all the five parents had predominance of recessive alleles with positive effects for days to first inflorescence appearance. The parent $\mathrm{P}_{3}$ contained maximum amount of recessive alleles whereas $\mathrm{P}_{1}$ contained minimum number of recessive alleles. Parent $\mathrm{P}_{2}$ and $\mathrm{P}_{3}$ gave the higher $\mathrm{Yr}^{\prime}$ values which indicated delayed appearance of first inflorescence in plant. Thus early inflorescence appearance was negatively associated with the direction of higher $\mathrm{Yr}$ ' value. It was found that $\mathrm{P}_{5}$ possessed the early appearance inflorescence among the parents. The highly significant value was observed for components $\mathrm{D}, \mathrm{H}_{1}, \mathrm{H}_{2}$ and $\mathrm{F}$ suggested the importance of both additive and dominance effects and their interaction in the expression of days to first inflorescence appearance. $\mathrm{H}_{2}$ and $\mathrm{h}_{2}$ indicated dominance with asymmetry and higher degree of dominance with negative effects, respectively.

The presence of partial dominance was reported for controlling the character days to first flowering as the regression line intersected the ' $\mathrm{Wr}$ ' axis above the point of origin. The array point of $\mathrm{P}_{4}$ located near the point of origin which revealed the presence of maximum frequency of dominant alleles and in contrast the parent $\mathrm{P}_{3}$ possessed maximum frequency of recessive alleles. $\mathrm{Vr}-\mathrm{Wr}$ graph also revealed genetic diversity among the parents for this character. The $\mathrm{Yr}^{\prime}-(\mathrm{Wr}+\mathrm{Vr})$ ' graph indicated predominance of recessive alleles with positive effect. The higher $\mathrm{Yr}^{\prime}$ values indicated that the parents $\mathrm{P}_{2}$ and $\mathrm{P}_{3}$ require maximum days for first flowering related with preponderance of recessive alleles in direction to higher positive effect. Thus it indicated that early days to first flowering was co-operated in the direction of lower values where parent $\mathrm{P}_{5}$ was depicted the earliness for this character. Positive significant measure for components $\mathrm{D}, \mathrm{H}_{1}, \mathrm{~F}$ and $\mathrm{E}$ indicated the essential role of additive, dominance, their interaction and environment for expression of days to first flowering in lablab bean. On the other hand, negative significant measure for the components $\mathrm{H}_{2}$ and $\mathrm{h}_{2}$ suggested that the dominance with asymmetry and higher degree of dominance in negative direction. As non-additive gene action was predominant for this trait and due to nonfeasibility of hybrid variety in lablab bean, diallel selective mating system may be adopted followed by biparental mating and recurrent selection for improvement of this trait.

The significant value of item ' $a$ ', ' $b$ ', ' $b_{2}$ ' and ' $b_{3}$ ' for the character of days to first edible pod maturity revealed the meaningful presence of additive, dominance, asymmetrical distribution of dominance and also dominance deviation for expressing this character in positive direction. The non-significant value for the item ' $b_{1}$ ' indicated the absence of unidirectional dominance. The regression line in ' $\mathrm{Vr}-\mathrm{Wr}$ ' graph revealed partial dominance for controlling the character days to edible pod maturity. Considering the distribution of array points, $\mathrm{P}_{3}$ and $\mathrm{P}_{1}$ contained higher amount of recessive and dominant alleles among the parent, respectively. The scattered array points along the regression line proved the higher genetic diversity among parents for this trait. The predominance of recessive alleles with positive effect was found for all the five parental score for controlling days to edible pod maturity in $\mathrm{Yr}^{\prime}-(\mathrm{Wr}+\mathrm{Vr})$ ' graph. The lower ' $\mathrm{Yr}$ ' value for parent $\mathrm{P}_{4}$ and $\mathrm{P}_{5}$ revealed that they required less time whereas $\mathrm{P}_{1}, \mathrm{P}_{2}$ and $\mathrm{P}_{3}$ parent needed higher time for edible pod maturity in lablab bean. The significant value of $\mathrm{D}, \mathrm{H}_{1}$ and $\mathrm{F}$ components revealed that the additive, dominance and their interaction effects played a key role for controlling days to edible pod maturity. The negative value for $\mathrm{H}_{2} / 4 \mathrm{H}_{1}$ was far from 0.25 which ensured unequal distribution of negative and positive alleles. 
The item ' $a$ ' and ' $b$ ' referred the presence of both additive and dominance components for controlling this character. Again, item ' $\mathrm{b}_{2}$ ' and ' $\mathrm{b}_{3}$ ' conveyed asymmetrical dominance and part of dominance deviation (which were not related to item ' $b_{1}$ ' and ' $b_{2}$ '), respectively. The non-significant value of item ' $b_{1}$ ' suggested the absence of unidirectional dominance for controlling days to seed maturity. The ' $\mathrm{Vr}-\mathrm{Wr}$ ' graph indicated presence of partial dominance for controlling days to seed maturity. The parent $\mathrm{P}_{2}$ was supposed to contain maximum frequency of dominant alleles whereas $\mathrm{P}_{3}$ contain maximum frequency of recessive alleles. The relative distribution of five parental score indicated the predominance of recessive alleles with positive effect. It was found from the $(\mathrm{Wr}+\mathrm{Vr})$ ' axis that the parent $\mathrm{P}_{2}$ contain minimum recessive alleles and $\mathrm{P}_{3}$ contained higher frequency of recessive alleles among the parents. Lower $\mathrm{Yr}^{\prime}$ value indicated that the parents $\mathrm{P}_{4}$ and $\mathrm{P}_{5}$ required less time for days to seed maturity. Significant positive measure for the components $\mathrm{D}, \mathrm{H}_{1}, \mathrm{~F}$ and $\mathrm{E}$ indicated the essential role of additive, dominance, their interaction and also environment for expressing the character days to seed maturity in lablab bean.

The significant value of item ' $a$ ' and ' $b$ ' ensured the presence of both additive and dominance components and unidirectional dominance was proved by item ' $b_{1}$ '. Asymmetric distribution of dominance and part of dominance deviation were suggested from item ' $b_{2}$ ' and ' $b_{3}$ ', respectively. It was revealed the presence of over dominance for controlling number of inflorescence per plant as the regression line intersected the 'Wr' axis below the point of origin in ' $\mathrm{Vr}-\mathrm{Wr}$ ' graph. This figure also showed genetic diversity among the parents in relation to this character. The parental graph clearly showed that all the five parents had predominance of recessive alleles with positive effects for number of inflorescences per plant. The highest ' $Y r$ ' value for the parent $\mathrm{P}_{3}$ indicated higher number of positive alleles for expression of inflorescences per plant. The positive significant value for components $\mathrm{D}, \mathrm{H}_{1}$ and $\mathrm{H}_{2}$ suggested the importance of both additive and dominance effects with asymmetrical distribution in positive direction for the expression of number of inflorescence per plant.

The significant value of item ' $a$ ' and ' $b$ ' revealed the presence of both additive and dominance components, respectively. Significant ' $\mathrm{b}_{1}$ ' value suggests unidirectional dominance. Asymmetric distribution of dominance and part of dominance deviation were suggested from item ' $\mathrm{b}_{2}$ ' and ' $\mathrm{b}_{3}$ ' for controlling number of nodes per inflorescence, respectively. Partial dominance was reported for controlling this character from the ' $\mathrm{Vr}-\mathrm{Wr}$ ' graph. It was further visible that $\mathrm{P}_{4}$ and $\mathrm{P}_{5}$ contain maximum frequency of dominant alleles and $\mathrm{P}_{1}$ possessed maximum frequency of recessive alleles among the parent. Distribution of array points revealed the presence of genetic diversity among the parents this character. The Yr'-(Wr+Vr)' graph indicated the predominance of recessive alleles with positive effect. The components $\mathrm{D}, \mathrm{H}_{1}, \mathrm{~F}$ and $\mathrm{E}$ indicated that the essential role of additive, dominance, their interaction and also environment for expressing the character number of nodes per inflorescence in lablab bean. Negative significant measure of $\mathrm{H}_{2}$ suggests the dominance with asymmetry in negative direction and positive significant value of $h_{2}$ indicates the higher degree of dominance with positive effects.

The items ' $a$ ' and ' $b$ ' referred the presence of both additive and dominance components for controlling this character. Non-significant value of item ' $b_{1}$ ' suggested the absence of unidirectional dominance for controlling number of pods per inflorescence and pods per plant. The $\mathrm{Vr}$-Wr graph confirmed the presence of over dominance for controlling the character of number of pods per inflorescence and complete dominance for pods per plant. This figure also showed genetic diversity among the parents in relation to these characters. High proportion of recessive alleles with positive effect was found for all the five parents for controlling number of pods per inflorescence in $\mathrm{Yr}^{\prime}-(\mathrm{Wr}+\mathrm{Vr})^{\prime}$ graph. It was notified that the parent $\mathrm{P}_{1}$ and $\mathrm{P}_{2}$ had the lower and higher number of pods per inflorescence, respectively. The highly significant value of the components $\mathrm{D}, \mathrm{H}_{1}$ and $\mathrm{F}$ for both the characters suggested the importance of both additive and dominance effects and their interaction in the expression of these characters. The components $\mathrm{H}_{2}$ and $\mathrm{h}_{2}$ indicated dominance with asymmetry and higher degree of dominance with negative effects, respectively. The significant of component $\mathrm{E}$ revealed the essential contribution of environment for both characters. 
The significant value for the item ' $a$ ', ' $b$ ', ' $b_{2}$ ' and ' $b_{3}$ ' revealed the meaningful presence of additive, dominance, asymmetrical distribution of dominance and also dominance deviation for expressing the traits edible pod length and pod breadth in positive direction. The non-significant value of item ' $b_{1}$ ' indicated the absence of unidirectional dominance. It was revealed the presence of partial dominance for expressing the character edible pod length and pod breadth from the ' $\mathrm{Vr}-\mathrm{Wr}$ ' graph. This figure also showed genetic diversity among the parents in relation to this character. The parental graph clearly showed that all the five parents had predominance of recessive alleles with positive effects for edible pod length. The graph $(\mathrm{Wr}+\mathrm{Vr})^{\prime}$ showed that $\mathrm{P}_{2}$ contained maximum amount of recessive alleles whereas $\mathrm{P}_{1}$ contained minimum number of recessive alleles among the five parents. The highest $\mathrm{Yr}^{\prime}$ value for parent $\mathrm{P}_{2}$ suggests higher edible pod length. Positive and significant measure of components $\mathrm{D}, \mathrm{H}_{1}, \mathrm{~F}$ and $\mathrm{E}$ indicated that the importance of additive, dominance, interaction of additive and dominance and environment for expressing edible pod length and pod breadth in lablab bean. In contrast, negative significant measure of components $\mathrm{H}_{2}$ suggests the dominance with asymmetry in negative direction. Again, positive significant value of $h_{2}$ indicated that higher degree of dominance in positive effects.

Edible pod weight was revealed the meaningful presence of additive, dominance, asymmetrical distribution of dominance, unidirectional distribution of dominance and part of dominance deviation for expressing this character in positive direction. It was revealed the presence of partial dominance for expressing the character edible pod weight from the Vr-Wr graph. The standardized graph showed that parents possessed negligible amount of dominant alleles. Majority of the array points situated at the middle part of the ' $\mathrm{Vr}-\mathrm{Wr}$ ' graph that suggested the parents contain equal proportion of dominant and recessive alleles. The parent $\mathrm{P}_{5}$ possessed maximum frequency of recessive alleles among the parent. The preponderance of recessive alleles with positive effect was found for all the five parental score for controlling this character in $\mathrm{Yr}^{\prime}-(\mathrm{Wr}+\mathrm{Vr})^{\prime}$ graph. The higher $\mathrm{Yr}^{\prime}$ score indicated that there was possibility of obtaining maximum pod weight from $\mathrm{P}_{1}$.

It was found positive significant measure for components $\mathrm{D}, \mathrm{H}_{1}, \mathrm{~F}$ and $\mathrm{E}$ that indicated the importance of additive, dominance, interaction of additive and dominance and environment for expressing pod weight in lablab bean (Table 3). Again, negative significant measure was found for components $\mathrm{H}_{2}$ that suggested the dominance with asymmetry in negative direction. The positive significant value was observed for component $h_{2}$ that indicated higher degree of dominance in positive effects.

The significant test of item ' $a$ ' and ' $b$ ' reported that both additive and dominance components played a vital role for regulating this eminent character. Significant value of item ' $b_{1}$ ' and ' $b_{2}$ ' indicated that the presence of unidirectional dominance and asymmetrical distribution of dominant gene for this character, respectively. Significant value of ' $b_{3}$ ' was depicted the part of dominance deviations which were not related to item ' $b_{1}$ ' and ' $b_{2}$ ' for expressing pod yield per plant. The regression line indicated presence of partial dominance for expressing the eminent character pod yield per plant. The distribution of array point of $\mathrm{P}_{5}$ revealed that this parent supposed to contain maximum frequency of dominant alleles; on the other hand array point of $\mathrm{P}_{1}$ suggested the presence of maximum frequency of recessive alleles. Genetic diversity among the parents in relation this character suggested by the scattered distribution of array points all along the regression line in ' $\mathrm{Vr}-\mathrm{Wr}$ ' graph. The consistency of dominance or recessive alleles with positive or negative effects in opposition to parental mean score was determined in the $\mathrm{Yr}^{\prime}-(\mathrm{Wr}+\mathrm{Vr})^{\prime}$ graph. It was clearly observed that all the five parents had predominance of recessive alleles with positive effects for this character. $\mathrm{P}_{2}$ possessed the highest $\mathrm{Yr}^{\prime}$ value which indicated the highest pod yield per plant. The significant value of the components $\mathrm{D}, \mathrm{H}_{2}$ and $\mathrm{h}_{2}$ indicated the importance of additive gene effect, dominance effect with asymmetry and higher degree of dominance in positive effect. The negative value for component $F$ suggested the eminent role of interaction of additive and dominance effect in negative direction for controlling pod yield per plant in lablab bean. Lowed KD/KR (-0.59) value than 1.0 indicated higher frequency of recessive alleles with the narrow sense heritability of pod yield per plant. As non-additive gene action was predominant for most of the traits and due to nonfeasibility of hybrid variety in lablab bean, diallel selective mating system may be adopted followed by biparental mating and recurrent selection for improvement of these traits. 


\section{ACKNOWLEDGMENTS}

The authors would like to acknowledge their gratitude towards university authority for the support from Bangabandhu Sheikh Mujibur Rahman Agricultural University, Gazipur 1706, Bangladesh through research program of Department of Genetics and Plant Breeding.

\section{REFERENCES}

Alhasan SA, O Aranha and FH Sarkar. 2001. Genistein elicits pleiotropic molecular effects on head and neck cancer cells. Clinical Cancer Research 7: 4174-4181.

Bagade AB, DU Patel, B Singh and NC Desai. 2002. Heterosis for yield and yield components in Indian bean. Indian Journal of Pulses Research 15 (1): 46-48.

Barua H, MH Rahman, MMA Patwary, MZ Alam and S Nahar. 2014. Variations in growth and yield of indigenous hyacinth bean (Lablab purpureus (L.) sweet) genotypes. The Agriculturists, 12(2): 01-05.

BBS. 2014. Yearbook of Agricultural Statistics - 2014, Bangladesh Bureau of Statistics (BBS), Statistics and informatics Division, Ministry of Planning.

Bhuvaneshwari A and AR Muthiah. 2005. Heterosis and inbreeding depression in lablab bean (Lablab purpureus, var. typicus). Legume Research 28 (2): 149-151.

Bitocchi E, L Nani, E Bellucci, M Rossi, A Giardini, ZP Spagnoletti, G Logozzo, J Stougaard, P McClean, G Attene and R Papa. 2002. Mesoamerican 35 origin of the common bean (Phaseolus vulgaris L.) is revealed by sequence data. Proceedings of the Natural Academy of Sciences, 109: 788-796.

Chacón SMI, B Pickersgill and DG Debouck. 2005. Domestication patterns in common bean (Phaseolus vulgaris L.) and the origin of the Mesoamerican and Andean cultivated races. Theoretical and Applied Genetics, 110: 432-444.

Cobely LS and WM Steele. 1976. An introduction to the botany of tropical plants. Longman Group Ltd., London. 96-98.

Cook BG, BC Pengelly and SD Brown. 2005. The production of tropical forages: An interactive selection tool. Tropical Forages, 46: 255-256.

Das I, T Seth, SV Durwas, S Dutta, A Chattopadhyay and B Sing. 2014. Gene action and combining ability for yield and yield component traits in dolichos bean (dolichos lablab var. typicus). SABRAO Journal of Breeding and Genetics, 46 (2): 293-304.

Deasi SB, VW Bendale, SG Bhave and RR Madav. 2006. Genetic analysis of growth and development characters in lablab bean (lablab purpureus (L.) sweet). International Journal of Agriculture Science, 2(1): 85-89.

Deka RK and CR Sarkar. 1990. Nutrient composition and anti-nutritional factors of Dolichos lablab L. seeds. Food Chemistry, 38: 239-246.

Fuller DQ. 2003. African crops in prehistoric South Asia: a critical review. In: Neumann, K., A. Butler, and S. Kahlheber (Eds.), Food, Fuel and Fields: Progress in African Archaeobotany, 239-271.

Gawali ST, V Khandelwal, DA Chauhan and VA Lodam. 2011. Heterosis and combining ability in Indian bean. Journal of Food Legumes, 24(2): 145-147.

Griffing B. 1956. Concept of general and specific combining ability in relation to diallel crossing system. Australian Journal of Biological Science, 9: 463-493.

Haider MZ, J Marumoto and AK Azad. 1991. Estimation of microbial biomass carbon and nitrogen in Bangladesh. Soil Science and Plant Nutrition, 37(4): 591-599.

Hayman BI. 1954. The theory and analysis of diallel crosses. Genetics, 39: 789-809.

Islam MS, MM Rahman and MAK Mian. 2011. Genetic variability, heritability and correlation study in hyacinth bean. Bangaldesh Journal of Agricultural Research, 35(3): 431-438.

Jinks JL. 1956. The $\mathrm{F}_{2}$ and backcross generations from a set of diallel crosses. Heredity, 10: 1-10.

Jones RM. 1965. The analysis of variance of the half diallel table. Heredity. 20: 117-121.

Khanam S. 1999. Genetic regulation of character expression and its interaction with environments in lablab purpureus. Pakistan Journal of Biological Science, 2(3): 647-650.

Khondker S and MA Newaz. 1998. Combining ability studies in lablab bean (Lablab purpureus L.) Annals of Bangladesh Agriculture, 8 (2): 143-149.

Kumar PA, RVSK Reddy, SR Pandravada, CVD Rani and V Chaitanya. 2014. Phenotypic variability, correlation and path coefficient analysis in pole type french beans (phaseolus vulgaris L.). Plant Archives, 14(1): 313-319.

Kumar S, V Magalingam and M Yassin. 2013. Genetic variability and character association in dolichos bean. SAARC Journal of Agriculture, 11(2):162.

Kobayashi T, T Nakata and T Kuzumaki. 2002. Effect of flavonoids on cell cycle progression in prostate cancer cells. Cancer Letters, 176: 17-23. 
Maass BL, MR Knox, SC Venkatesha, TT Angessa, S Ramme and BC Pengelly. 2010. Lablab purpureus - a crop lost for Africa? Tropical Plant Biology, 3(3): 123-135.

Maass BL and BC Pengelly. 2001. Lablab purpureus (L.) Sweet - diversity, potential use and determination of a core collection of this multi - purpose tropical legume. Genetic Resources and Crop Evolution, 48: 261272.

Maras M, J Ŝŝstar-Vozliĉ, W Kainz and V Megliĉ. 2013. Genetic diversity and dissemination pathways of common bean in Central Europe. Journal of the American Society for Horticultural Science, 138: 297-305.

Modha KG, KB Kathria and AR Tukadiya. 2007. Combining ability analysis for pod yield and its related traits in Indian bean (Lablab purpureus var. lignosus). Journal of Vegetable Science, 34(1): 89-91.

Mohan N, TS Aghora and MA Wani. 2014. Studies on genetic variability in dolichos bean (Lablab purpureus L.). The Journal of horticultural Science and Biotechnology, 9(1):82-85.

Murphy AM and PE Colucci. 1999. A tropical forage solution to poor quality ruminant diets: a review of Lablab purpureus. Livestock Research for Rural Development 11(2):112.

Naeem M, MMA Khan, Moinuddin and MH Siddiqui. 2009. Triacontanol stimulates nitrogen fixation, enzyme activities, photosynthesis, crop productivity and quality of hyacinth bean (Lablab purpureus L.). Scientia Horticulturae, 121(4): 389-396.

Newaz N. 1992. The composition of germinating lablab bean seed and the functional characteristics of its flour. Journal of the Bangladesh Agricultural University. 6: 230-237.

Parmar AM, AP Singh, NPS Dhillon and M Jamwal. 2013. Genetic variability studies for morphological and yield traits in dolichos bean (Lablab purpureus L.). World Journal of Agricultural Sciences, 9(1): 24-28.

Patil, AB, DT Desai, SA Patil and UR Ghodke. 2013. Diallel analysis for pod yield and its components traits in vegetable Indian bean. African Journal of Agricultural Research, 8(14): 1229-1232.

Philip T. 1982. Induced tetraploidy in Dolichos lablab (Linn.). Current Science, 51: 945

Purseglove JW. 1977. Tropical crops, dicotyledons. Longman Group Ltd., London. 273- 276.

Raihan MS and MA Newaz. 2008. Combining ability for quantitative attributes in lablab bean (lablab purpureus L. ). Bangladesh Journal of Plant Breeding and Genetics, 21(1): 29-34.

Rashid MM. 1999. Shabji Biggan. Rashid Publishing House, 94, Old DOHS, Dhaka-1206, 307-409.

Salim M, S Hossain, S Alam, JA Rashid and S Islam. 2013. Variability, correlation and path analysis in lablab bean (Lablab purpureus L.). Bangaldesh Journal of Agricultural Research, 38(4): 705-717.

Santalla M, AMD Ron and MDL Fuente. 2010. Integration of genome and phenotypic scanning gives evidence of genetic structure in Mesoamerican common bean (Phaseolus vulgaris L.) landraces from the southwest of Europe. Theoretical and Applied Genetics 120: 1635-1651.

Sen S, RL Patel, RA Patel, KG Modha and RK Patel. 2018. Analysis of Combining Ability and Gene Action in Indian bean [Lablab purpureus (L.) Sweet]. International Journal of Current Microbiology and Applied Sciences, 7(4): 1790-1798.

Sharma PN, LM Díaz and MW Blair. 2013. Genetic diversity of two Indian common bean germplasm collections based on morphological and microsatellite markers. Plant Genetic Resources 11: 121-130.

Shibly MMR. 2014. Morphological characterization of country bean (Lablab purpureus) genotypes collected from coastal region of Bangladesh. 17

Shivashankar G and RS Kulkarni. 1989. Field bean (Dolichos lablab Linn. var. lignosus Prain). Indian Horticulture, 34: 24-27.

Sprague GF and LA Tatum. 1942. General vs. specific combining ability in single crosses of corn. Journal of American Society of Agronomy, 34 (9): 23-32.

Srivastava OP and PN Bajpai. 1977. Combining ability in eggplant. Indian Journal of Agricultural Science 47(4): 181-184.

Valenzuela H and J Smith. 2002. Sustainable agriculture green manure crops. Cooperative Extension Service, College of Tropical Agriculture and Human Resources, University of Hawaii at Manoa. 85-86.

Verhalen LM and JC Murray. 1969. A diallel analysis of several fiber properties traits in upland cotton (Gossypium hirsutum L.). Crop Science, 9: 311-315.

Virja NR, VJ Bhatiya and VK. Poshiya. 2006. Heterosis and combining ability in Indian bean (Lablab purpureus (L.) sweet). Agricultural Science Digest, 26(1): 6-10.

Zhang X, MW Blair and S Wang. 2008. Genetic diversity of Chinese common bean (Phaseolus vulgaris L.) landraces assessed with simple sequence repeat markers. Theoretical and Applied Genetics, 117: 629-640.

Wynne JC and TA Coffelt. 1973. Genetics of Arachis hypogaea L. (HE Pattee and CT Wilson, eds, Peanut Science and Technology). Amer. Peanut Res. Educ. Soc., Yoakum, Texas; pp. 50-94.

||------||-------|| 